\title{
Irlactane and Tremulane Sesquiterpenes from the Cultures of the Medicinal Fungus Irpex lacteus HFG1 102
}

\author{
He-Ping Chen ${ }^{1}\left(\mathbb{0} \cdot \mathrm{Xu} \mathrm{Ji}^{2} \cdot\right.$ Zheng-Hui Li $^{1} \cdot$ Tao Feng $^{1} \cdot \mathrm{Ji}^{-K a i} \mathrm{Liu}^{1}$
}

Received: 9 January 2020 / Accepted: 26 March 2020 / Published online: 10 April 2020

(c) The Author(s) 2020

\begin{abstract}
A new irlactane-type, namely irlactin K (1), and 22 tremulane-type sesquiterpenes including fourteen previously undescribed ones, namely irpexolactins A-N (2-15), and a known irlactane-type sesquiterpenoid, were isolated from the fermentation broth of the medicinal fungus Irpex lacteus HFG1102. The structures of all the isolates were characterized by extensive spectroscopic methods, including 1D and 2D NMR and MS spectroscopic analysis. The absolute configurations of irlactin K and the known compound conocenol B (20) were established by single-crystal X-ray diffraction analysis. The vasorelaxant effects of irlactin K (1), irpexolactins A (2), C (4), K (12), and irlactam (22) were evaluated.
\end{abstract}

\section{Graphic Abstract}

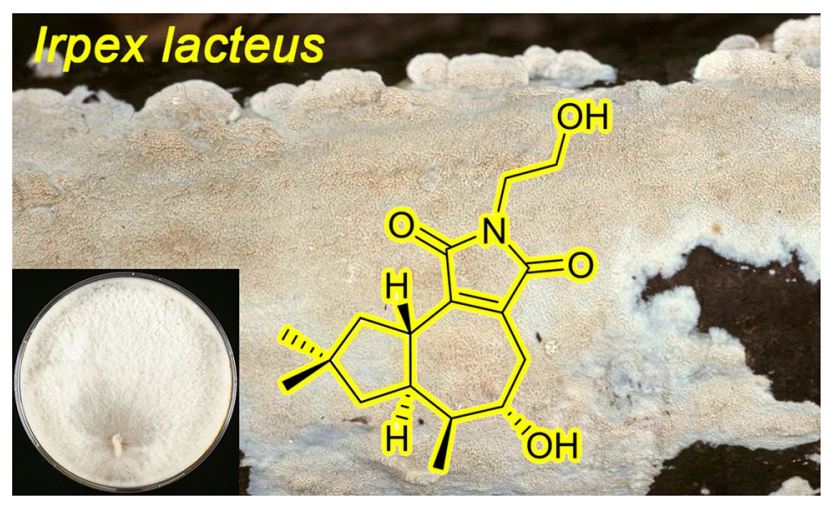

Keywords Irpex lacteus $\cdot$ Meruliaceae $\cdot$ Irlactane $\cdot$ Tremulane $\cdot$ Sesquiterpene

The article is dedicated to Professor Han-Dong Sun on occasion of his 80th birthday.

\section{Electronic supplementary material The online version of this} article (https://doi.org/10.1007/s13659-020-00239-z) contains supplementary material, which is available to authorized users.

Ji-Kai Liu

jkliu@mail.kib.ac.cn; liujikai@mail.scuec.edu.cn

1 School of Pharmaceutical Sciences, South-Central University for Nationalities, Wuhan 430074, People's Republic of China

2 School of Chemical Science and Technology, Yunnan University, Kunming 650091, People's Republic of China

\section{Introduction}

Medicinal fungi are dominate resources of natural products with diverse structural scaffolds and promising biological activities [1]. The wood-decaying fungus Irpex lacteus widely distributed throughout temperate areas globally is traditionally used as a medicinal fungus for diuretic, antibacterial, and anti-inflammatory function. The Yishenkang capsule made from the fermentated polysaccharide fraction of this fungus is clinically used as a remedy for chronic glomerulonephritis in China [2]. However, the fungus has not yet been fully chemically explored. 
Tremulanes are a class of 5/7-ring-fused sesquiterpenoid which are typically found from fungi [1], and were originally isolated from the wood-decaying fungus Phellinus tremulae [3], and later from the medicinal fungus Phellinus igniarius, and the mushroom Conocybe siligi$n e a$. Recently, we reported ten tremulane/tremulanerelated sesquiterpenoids, namely irlactins $\mathrm{A}-\mathrm{J}$ from the cultures of the fungus I. lacteus, among which irlactins A-D featured by an unprecedented skeleton in sesquiterpenoid class [4-6]. Herein, as part of our ongoing research for secondary metabolites as promising drug leads from higher fungi, we reported fifteen previously undescribed irlactane/tremulanes, namely irlactin $\mathrm{K}$ (1), and irpexolactins A-N (2-15) (Fig. 1), along with nine known ones from the culture broth of the fungus $I$. lacteus.

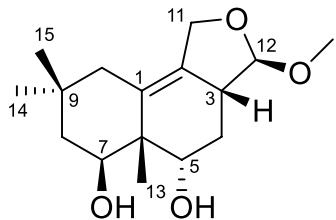

1<smiles>CC1C2CC(C)(C)CC2=C(CO)[C@@H]2CO[C@]1(O)C2</smiles>
5<smiles>[R7]C1([R])OCC2=C3CC(C)(C)C[C@H]3[C@@H](C)[C@@H](O)C[C@H]21</smiles>

$6 \mathrm{R}^{1}=\mathrm{H}, \mathrm{R}^{2}=\mathrm{OH}$

$7 \mathrm{R}^{1}=\mathrm{OH}, \mathrm{R}^{2}=\mathrm{H}$

$8 R^{1}, R^{2}=0$

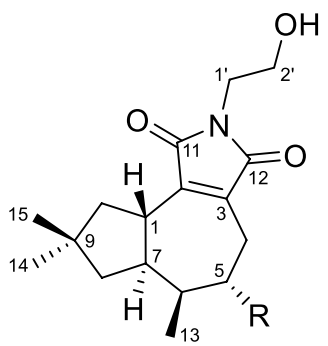

$2 \mathrm{R}=\mathrm{OH}$

$22 \mathrm{R}=\mathrm{H}$<smiles>C[C@H]1C(=O)CC(CO)C(CO)=C2CC(C)(C)C[C@H]21</smiles>

23

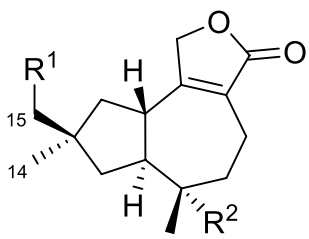

$9 \mathrm{R}^{1}=\mathrm{H}, \mathrm{R}^{2}=\mathrm{OH}$

$10 \mathrm{R}^{1}=\mathrm{OAc}, \mathrm{R}^{2}=\mathrm{H}$

$11 \mathrm{R}^{1}=\mathrm{OH}, \mathrm{R}^{2}=\mathrm{H}$

$17 \mathrm{R}^{1}=\mathrm{H}, \mathrm{R}^{2}=\mathrm{H}$

\section{Results and Discussion}

\subsection{Structure Elucidation of Previously Undescribed Fungal Metabolites (1-15)}

Irlactin $\mathrm{K}(\mathbf{1})$ was isolated as colorless crystals. The ${ }^{1} \mathrm{H}$ NMR spectroscopic data (Table 1) presented three methyl singlets $\left(\delta_{\mathrm{H}} 0.88,1.00,1.23\right)$ and a methoxy group $\left(\delta_{\mathrm{H}} 3.44\right)$. The ${ }^{13} \mathrm{C}$ NMR spectrum (Table 4 ) showed sixteen carbon resonances ascribable to four methyls, four methylenes (one oxygenated), four methines (three oxygenated), and four quaternary carbons. All these data are reminiscent of those of irlactins $\mathrm{C}$ and $\mathrm{D}$ which were isolated from the cultures of the same fungus but different strains [4]. The presence of a methoxy group rather than a hydroxy group at $\mathrm{C}-12$ in $\mathbf{1}$ as suggested by the HMBC correlation from the methoxy at $\delta_{\mathrm{H}} 3.44$ to the ketal carbon at $\delta_{\mathrm{C}} 111.3(\mathrm{C}-12)$ discriminated its structure from those of irlactins $\mathrm{C} / \mathrm{D}$. The above assignments led to<smiles>C[C@@H]1CC2=C3C(=O)N(CCO)C(=O)[C@]3(O)CC[C@H](C)[C@@H]2C1</smiles>

3<smiles>CO[C@]12CC(CO)=C3CC(C)(C)C[C@H]3[C@@H](C)[C@H]1C2</smiles>

16<smiles>[R]OC[C@@H]1C(CO)=C2CC(C)(C)C[C@@H]2[C@@H]([R1])CC1[R]</smiles>

\begin{tabular}{ccccc} 
& $\mathrm{R}^{1}$ & $\mathrm{R}^{2}$ & $\mathrm{R}^{3}$ & $\mathrm{R}^{4}$ \\
\hline 12 & $\mathrm{H}$ & $\mathrm{H}$ & $\mathrm{OH}$ & $\mathrm{H}$ \\
13 & $\mathrm{H}$ & $\mathrm{Ac}$ & $\mathrm{H}$ & $\mathrm{H}$ \\
14 & $\mathrm{OH}$ & $\mathrm{H}$ & $\mathrm{H}$ & $\mathrm{H}$ \\
15 & $\mathrm{H}$ & $\mathrm{Ac}$ & $\mathrm{H}$ & $\mathrm{OH}$
\end{tabular}

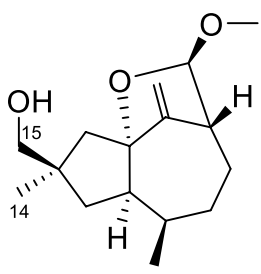

4

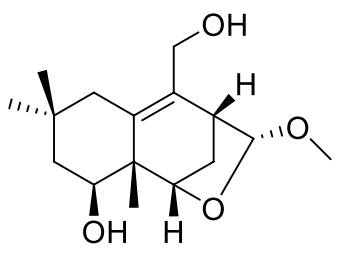

24

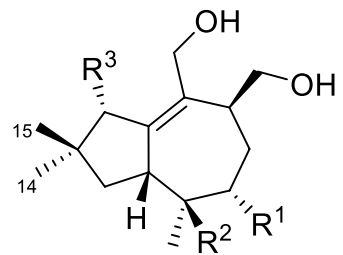

\begin{tabular}{cccc} 
& $\mathrm{R}^{1}$ & $\mathrm{R}^{2}$ & $\mathrm{R}^{3}$ \\
\hline $\mathbf{1 8}$ & $\mathrm{H}$ & $\mathrm{H}$ & $\mathrm{H}$ \\
$\mathbf{1 9}$ & $\mathrm{H}$ & $\mathrm{OH}$ & $\mathrm{H}$ \\
$\mathbf{2 0}$ & $\mathrm{OH}$ & $\mathrm{H}$ & $\mathrm{H}$ \\
$\mathbf{2 1}$ & $\mathrm{H}$ & $\mathrm{H}$ & $\mathrm{OH}$
\end{tabular}

Fig. 1 Structures of compounds 1-24 
Table $1{ }^{1} \mathrm{H}$ NMR spectroscopic data of compounds $\mathbf{1}-\mathbf{5}(600 \mathrm{MHz}, \delta$ in ppm)

\begin{tabular}{|c|c|c|c|c|c|}
\hline No & $\mathbf{1}^{\mathrm{a}}$ & $2^{\mathrm{a}}$ & $3^{b}$ & $4^{\mathrm{c}}$ & $5^{\mathrm{a}}$ \\
\hline 1 & & 2.83 , overlapped & & & \\
\hline 3 & $2.45, \mathrm{~m}$ & & & 2.66, dd $(3.7,3.7)$ & 2.98, dd $(7.4,7.4)$ \\
\hline 4 & $\begin{array}{l}1.99, \text { ddd }(11.6,5.0,3.6) \\
1.59, \text { dd }(11.6,11.6)\end{array}$ & $\begin{array}{l}\text { 2.81, overlapped } \\
2.65 \text {, ddd }(17.3,3.0,3.0)\end{array}$ & $\begin{array}{l}1.98, \text { ddd }(14.5,4.2,2.5) \\
1.76, \text { dd }(14.5,3.0)\end{array}$ & $\begin{array}{l}\text { 1.77, dddd }(13.7,13.7,3.7 \text {, } \\
\text { 3.7) } \\
\text { 1.68, overlapped }\end{array}$ & $\begin{array}{l}2.00, \mathrm{~d}(12.3) \\
1.83, \mathrm{dd}(12.3,7.4)\end{array}$ \\
\hline 5 & 3.76 , dd $(11.6,3.6)$ & 3.63 , overlapped & $\begin{array}{l}\text { 2.44, dddd }(14.4,14.4,3.3 \text {, } \\
\text { 3.3) } \\
1.74, \mathrm{~m}\end{array}$ & $\begin{array}{l}1.95, \mathrm{~m} \\
1.59, \mathrm{~m}\end{array}$ & \\
\hline 6 & & $1.98, \mathrm{~m}$ & $1.96, \mathrm{~m}$ & $2.10, \mathrm{~m}$ & $1.92, \mathrm{~m}$ \\
\hline 7 & $4.07, \mathrm{dd}(11.2,5.3)$ & $2.59, \mathrm{~m}$ & $3.59, \mathrm{~m}$ & 2.40, ddd $(14.3,6.6,6.6)$ & $3.25, \mathrm{~m}$ \\
\hline 8 & $\begin{array}{l}1.53, \mathrm{dd}(13.5,11.2) \\
1.48, \mathrm{dd}(13.5,5.3)\end{array}$ & $\begin{array}{l}\text { 1.49, dd }(14.2,1.5) \\
1.45, \mathrm{~d}(14.2)\end{array}$ & $\begin{array}{l}1.65, \text { br dd }(12.5,8.4) \\
1.45, \mathrm{dd}(12.5,11.0)\end{array}$ & $\begin{array}{l}\text { 1.67, overlapped } \\
1.14 \text {, dd }(12.5,6.0)\end{array}$ & $\begin{array}{l}1.51, \mathrm{dd}(12.1,12.1) \\
1.46, \mathrm{dd}(12.1,8.5)\end{array}$ \\
\hline 10 & $\begin{array}{l}1.96, \text { br d (13.5) } \\
1.78, \text { br d (13.5) }\end{array}$ & $\begin{array}{l}2.32, \mathrm{dd}(12.9,7.6) \\
1.54, \mathrm{dd}(12.9,10.9)\end{array}$ & $\begin{array}{l}3.25, \mathrm{~d}(17.8) \\
2.19, \mathrm{~d}(17.8)\end{array}$ & $\begin{array}{l}2.17, \mathrm{~d}(14.8) \\
1.65, \mathrm{~d}(14.8)\end{array}$ & $\begin{array}{l}2.30, \text { br d (15.7) } \\
1.99, \text { br d (15.7) }\end{array}$ \\
\hline 11 & 4.31 , br s & & & $\begin{array}{l}5.13, \mathrm{~s} \\
4.94, \mathrm{~s}\end{array}$ & $\begin{array}{l}4.07, \mathrm{~d}(12.1) \\
3.95, \mathrm{~d}(12.1)\end{array}$ \\
\hline 12 & $4.64, \mathrm{~d}(6.0)$ & & & $4.62, \mathrm{~s}$ & $\begin{array}{l}4.32, \mathrm{dd}(7.8,7.4) \\
3.84, \mathrm{~d}(7.8)\end{array}$ \\
\hline 13 & $1.23, \mathrm{~s}$ & $1.03, \mathrm{~d}(7.0)$ & $0.84, \mathrm{~d}(7.0)$ & $0.89, \mathrm{~d}(7.0)$ & $0.87, \mathrm{~d}(7.0)$ \\
\hline 14 & $0.88, \mathrm{~s}$ & $1.07, \mathrm{~s}$ & $0.89, \mathrm{~s}$ & $1.10, \mathrm{~s}$ & $1.11, \mathrm{~s}$ \\
\hline 15 & $1.00, \mathrm{~s}$ & $1.07, \mathrm{~s}$ & $1.17, \mathrm{~s}$ & $\begin{array}{l}3.39, \mathrm{~d}(10.0) \\
3.37, \mathrm{~d}(10.0)\end{array}$ & $0.94, \mathrm{~s}$ \\
\hline $1^{\prime}$ & & $3.56, \mathrm{t}(5.6)$ & $3.78, \mathrm{t}(5.2)$ & & \\
\hline $2^{\prime}$ & & $3.63, \mathrm{t}(5.6)$ & $3.83, \mathrm{t}(5.2)$ & & \\
\hline $2^{\prime}-\mathrm{OH}$ & & & 2.57 , br s & & \\
\hline$-\mathrm{OMe}$ & $3.44, \mathrm{~s}$ & & & $3.19, \mathrm{~s}$ & \\
\hline
\end{tabular}

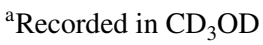

${ }^{\mathrm{b}}$ Recorded in $\mathrm{CDCl}_{3}$

${ }^{\mathrm{c}}$ Recorded in acetone- $d_{6}$

the determination of the planar structure of $\mathbf{1}$ as depicted in Fig. 2. The absolute configuration of $\mathbf{1}$ was determined to be $3 R, 5 S, 6 R, 7 S, 12 R$ via $\mathrm{X}$-ray single crystal diffraction analysis with the small Flack parameter 0.15(6) (Fig. 3).

Irpexolactin A (2) was obtained as a pale-yellow oil. The molecular formula $\mathrm{C}_{17} \mathrm{H}_{25} \mathrm{O}_{4} \mathrm{~N}$ with six degrees of unsaturation was deduced from the sodium adduct ion peak at $m / z 330.1685[\mathrm{M}+\mathrm{Na}]^{+}$in the HRESIMS analysis (calcd for $\mathrm{C}_{17} \mathrm{H}_{25} \mathrm{O}_{4} \mathrm{NNa}, 330.1676$ ). The ${ }^{1} \mathrm{H}$ and ${ }^{13} \mathrm{C}$ NMR data of 2 (Tables 1,4) revealed the presence of three methyls (two singlets at $\delta_{\mathrm{H}} 1.07,1.07$, one doublet at $\delta_{\mathrm{H}}$ 1.03), five methylenes (one oxygenated at $\delta_{\mathrm{C}} 60.4$ ), four methines (one oxygenated at $\delta_{\mathrm{C}} 74.7$ ), and five quaternary carbons (two carbonyls at $\delta_{\mathrm{C}} 172.7, \mathrm{C}-11 ; 173.2, \mathrm{C}-12$ ) and a tetrasubstituted double bond at $\delta_{\mathrm{C}} 145.5(\mathrm{C}-2), 139.4$ (C-3), indicating three double bond equivalences. All these data bore striking similarity with those of coriolopsin A, a tremulane sesquiterpene isolated from the endophytic fungus Coriolopsis sp. J5 [7]. The structure of compound 2 was further corroborated by 2D NMR analysis, which suggested that the $\Delta^{1}$ double bond in coriolopsin A shifted to $\Delta^{2}$ in 2 by HMBC correlation from $\mathrm{H}-1\left(\delta_{\mathrm{H}} 2.83\right), \mathrm{H}_{2}-4$ $\left(\delta_{\mathrm{H}} 2.81,2.65\right)$ to $\mathrm{C}-2$ and $\mathrm{C}-3$ (Fig. 2). Furthermore, the oxygenated methine at $\delta_{\mathrm{C}} 74.7$ was assigned to C-5 by the HMBC correlation from $\mathrm{H}_{3}-13\left(\delta_{\mathrm{H}} 1.03\right)$ to $\mathrm{C}-5$ and ${ }^{1} \mathrm{H}-$ ${ }^{1} \mathrm{H}$ COSY correlation between $\mathrm{H}-5\left(\delta_{\mathrm{H}} 3.63\right)$ and $\mathrm{H}-6\left(\delta_{\mathrm{H}}\right.$ 1.98) (Fig. 2). The remaining two methylenes was assigned to an aminoethanol group same as that harbored in vibralactamide A [8] according to the chemical shifts of C-1' $\left(\delta_{\mathrm{C}} 41.3\right), \mathrm{C}-2^{\prime}\left(\delta_{\mathrm{C}} 60.4\right)$ and the ${ }^{1} \mathrm{H}-{ }^{1} \mathrm{H}$ COSY correlations between $\mathrm{H}-1^{\prime}\left(\delta_{\mathrm{H}} 3.56\right) / \mathrm{H}-2^{\prime}\left(\delta_{\mathrm{H}} 3.63\right)$. The $\mathrm{HMBC}$ correlations from $\mathrm{H}-1^{\prime}$ to two carbonyls at $\mathrm{C}-11$ and $\mathrm{C}-12$, revealed a succinamide moiety.

Compound 2 possessed a 1-(2-hydroxyethyl)pyrrolidine-2,5-dione unit which is unusual in sesquiterpenoid family. The relative configuration of $\mathbf{2}$ was ascertained by the ROESY spectrum. The ROESY correlations of $\mathrm{H}-1 / \mathrm{H}_{3}-$ 13/H-5, and H-6/H-7 demonstrated that when 5-OH and H-7 occupied $\alpha$ orientation, $\mathrm{H}-1$ and Me- 13 would be $\beta$ orientation (Fig. 4). All the above assignments successfully constructed the structure of $\mathbf{2}$ (Fig. 1) and irpexolactin A was given as the trivial name. 


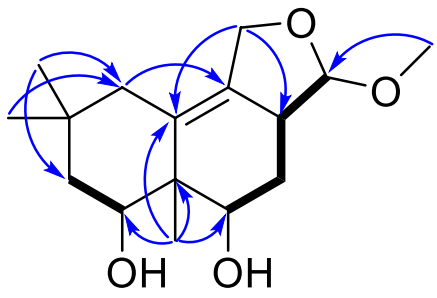

1

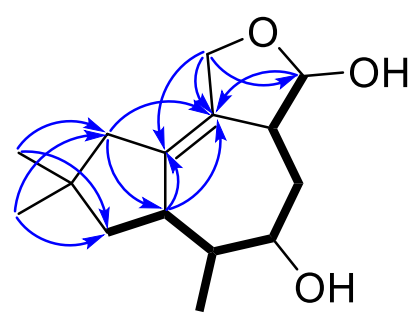

$6 / 7$

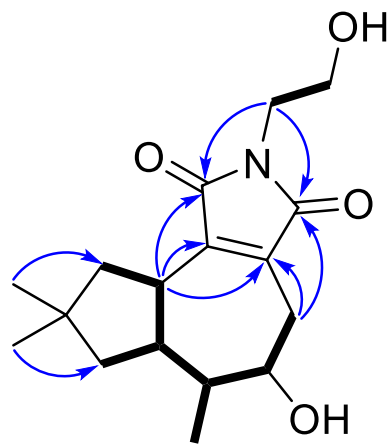

2

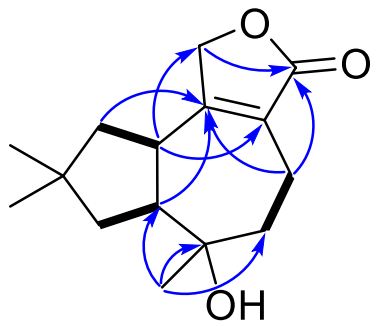

9

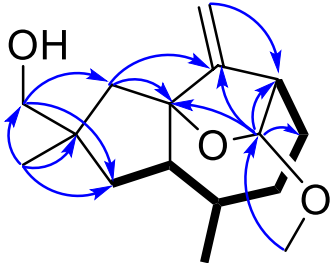

4

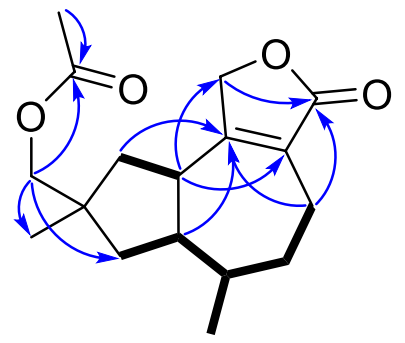

10

\section{- ${ }^{1} \mathrm{H}-{ }^{1} \mathrm{H} \operatorname{COSY}$}

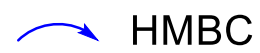

Fig. 2 Key ${ }^{1} \mathrm{H}^{1}{ }^{1} \mathrm{H}$ COSY and $\mathrm{HMBC}$ correlations of compounds $1,2,4,6 / 7,9$, and 10

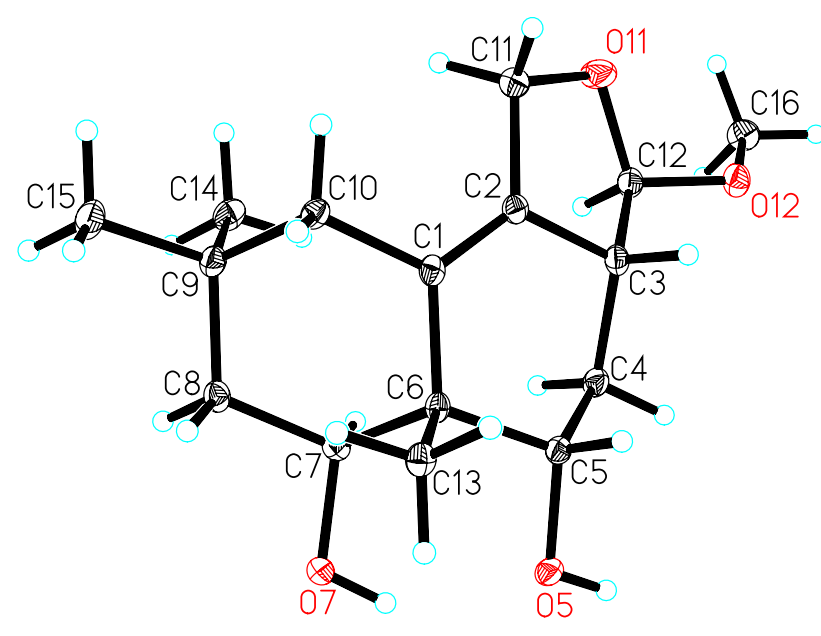

Fig. 3 ORTEP drawing of compound 1

The colorless oil 3 had a molecular formula of $\mathrm{C}_{17} \mathrm{H}_{25} \mathrm{NO}_{4}$ identical with that of $\mathbf{2}$ as suggested by HRESIMS result. The ${ }^{13} \mathrm{C}$ NMR data of irlactam (22) [6] and 3 (Table 4) displayed remarkable disparities of $\mathrm{C}-1, \mathrm{C}-2$, and $\mathrm{C}-3$, suggesting their main differences located at $\mathrm{C}-1$ to $\mathrm{C}-3$. The HMBC correlations from H-7 $\left(\delta_{\mathrm{H}} 3.59\right), \mathrm{H}-10\left(\delta_{\mathrm{H}} 3.25\right.$ and 2.19$)$ to $\mathrm{C}-1\left(\delta_{\mathrm{C}} 170.1\right), \mathrm{C}-2\left(\delta_{\mathrm{C}} 123.3\right)$, and from $\mathrm{H}-4\left(\delta_{\mathrm{H}} 1.98\right.$ and 1.76) to C-2, C-3 $\left(\delta_{\mathrm{C}} 74.4\right)$ enabled the assignments of double bond between $\mathrm{C}-1$ and $\mathrm{C}-2$, and a hydroxy attached to C-3. The ROESY correlations between H-6 $\left(\delta_{\mathrm{H}} 1.96\right)$ and $\mathrm{H}-7$ revealed that the $\beta$ orientation of Me- 13 and $\alpha$ orientation of H-7. However, the configuration of 3-OH remained undetermined due to the shortage of sample for making any chemical derivatives. Thus, the structure of compound $\mathbf{3}$ was determined as shown in Fig. 1, and was named irpexolactin B.

Compound 4 was obtained as a colorless oil. The HRESIMS experiment gave a sodium adduct ion peak at $\mathrm{m} / \mathrm{z}$ $289.1774[\mathrm{M}+\mathrm{Na}]^{+}$, corresponding to a molecular formula of $\mathrm{C}_{16} \mathrm{H}_{26} \mathrm{O}_{3}$ (calcd for $\mathrm{C}_{16} \mathrm{H}_{26} \mathrm{O}_{3} \mathrm{Na}$, 289.1774) with four double bond equivalences. The 1D NMR data (Tables 1,4) displayed three methyls (one methoxy), six methylenes (one oxygenated, a terminal double bond), four methines (one acetal methine), and three quaternary carbons (one oxygenated, one embedded into a terminal double bond). All these data are reminiscent of the known compound $1 \beta, 12$-epoxy14-hydroxy-2(11)-tremulene [9]. The HMBC correlations from $\mathrm{H}-12\left(\delta_{\mathrm{H}} 4.62\right)$ to $\mathrm{C}-1\left(\delta_{\mathrm{C}} 93.7\right), \mathrm{C}-2\left(\delta_{\mathrm{C}} 156.1\right), \mathrm{C}-3$ $\left(\delta_{\mathrm{C}} 52.2\right)$, and C-4 $\left(\delta_{\mathrm{C}} 26.7\right)$, and from the methoxy at $\delta_{\mathrm{H}}$ 3.19 to $\mathrm{C}-12\left(\delta_{\mathrm{C}} 106.2\right)$ indicated that the methylene $\mathrm{C}-12$ in 1 $\beta, 12$-epoxy-14-hydroxy-2(11)-tremulene was substituted by a methoxy to give 4 (Fig. 2). The ROESY correlations 


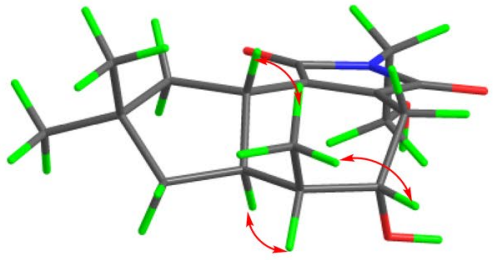

2

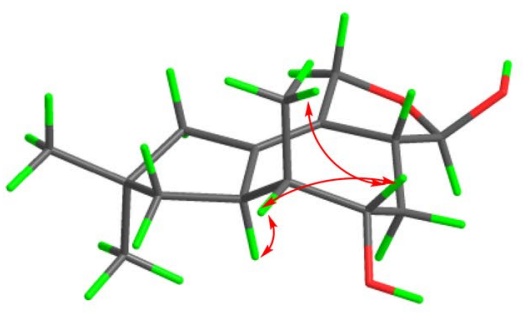

7

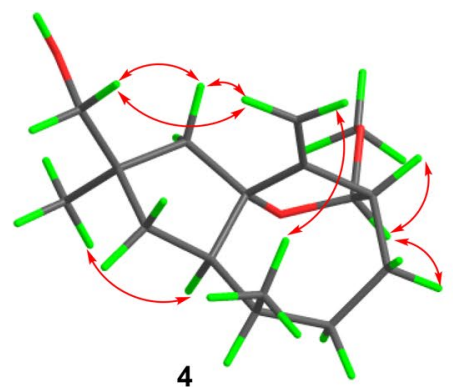

4

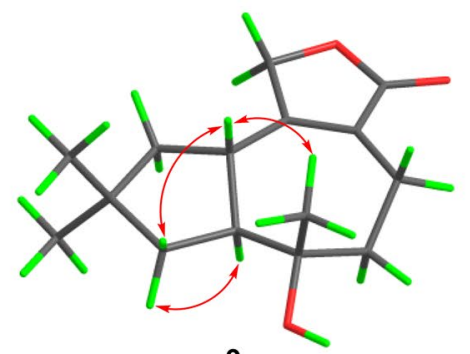

9

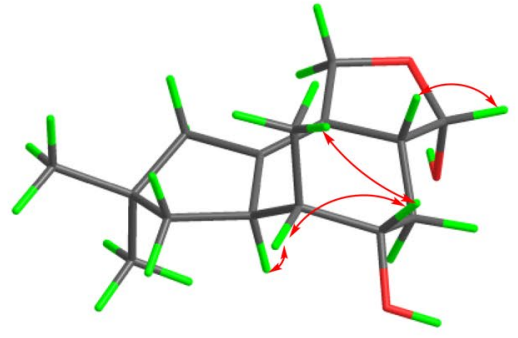

6

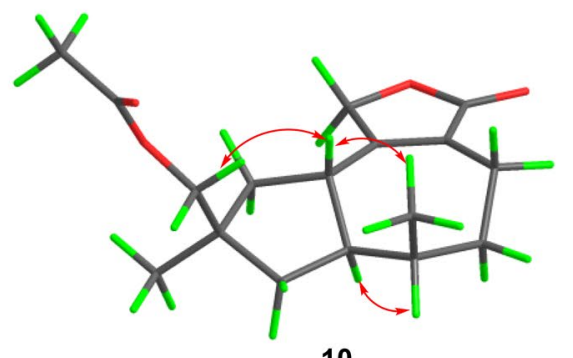

10

Fig. 4 Key ROESY correlations of compounds 2, 4, 6/7, 9, and 10

of $\mathrm{H}_{3}-13\left(\delta_{\mathrm{H}} 0.89\right) / \mathrm{H}_{2}-11\left(\delta_{\mathrm{H}} 5.13,4.94\right), \mathrm{H}_{2}-15\left(\delta_{\mathrm{H}} 3.39\right.$, $3.37) / \mathrm{H}-11 \mathrm{a}$, and $\mathrm{H}_{3}-14\left(\delta_{\mathrm{H}} 1.10\right) / \mathrm{H}-7\left(\delta_{\mathrm{H}} 2.40\right)$ demonstrated the $\beta$ orientations for Me- 13 and $15-\mathrm{CH}_{2} \mathrm{OH}$ (Fig. 4), which is different to that of $1 \beta, 12$-epoxy-14-hydroxy-2(11)tremulene. The key ROESY correlations of $\mathrm{H}-12\left(\delta_{\mathrm{H}} 4.62\right) /$ $\mathrm{H}-3\left(\delta_{\mathrm{H}} 2.66\right), \mathrm{H}-12 / \mathrm{H}-4 \beta\left(\delta_{\mathrm{H}} 1.68\right)$ (Fig. 4) helped to assign the relative configuration of $\mathrm{C}-12$ as $R^{*}$ and $\alpha$ oriented. Thus, compound $\mathbf{4}$ was established as irpexolactin $\mathrm{C}$.

Compounds 5 and $\mathbf{2 3}$ were inseparable mixture with a ratio of 1:1.6. HRESIMS results revealed that they had the same molecular formula as $\mathrm{C}_{15} \mathrm{H}_{24} \mathrm{O}_{3}(\mathrm{~m} / \mathrm{z}, 275.1624$ $[\mathrm{M}+\mathrm{Na}]^{+}$, calcd for $\left.\mathrm{C}_{15} \mathrm{H}_{24} \mathrm{O}_{3} \mathrm{Na}, 275.1618\right)$. The NMR spectroscopic analysis of the mixture led to the identification of 11,12-dihydroxy-1-tremulen-5-one (23), a known tremulane sesquiterpenoid isolated from the mushroom Conocybe siliginea [10]. The remaining spectroscopic signals were ascribable to three methyls, five methylenes (two oxygenated), three methines, and four quaternary carbons (two olefinic, one ketal carbon) (Tables 1, 4). All these data showed resemblance with those of conocenol C (16) [11], except substituted patterns at $\mathrm{C}-5$. In compound $\mathbf{5}$, a hydroxy group was attached to $\mathrm{C}-5$, while in conocenol $\mathrm{C}$ a methoxy instead, which was deferred by HMBC correlation from $\mathrm{H}-12\left(\delta_{\mathrm{H}} 4.32\right.$ and 3.84$)$ to $\mathrm{C}-5\left(\delta_{\mathrm{C}} 112.8\right)$ and the HRESIMS data. Notably, the inseparable mixture of $\mathbf{5}$ and $\mathbf{2 3}$ seems to be the interconversion of hemiketal form $\mathbf{5}$ and ketone form 23. Therefore, compound 5 was identified as irpexolactin D (shown in Fig. 1).

Compounds 6 and 7 were inseparable mixture with a ratio of 1.9:1 according to the integration of ${ }^{1} \mathrm{H}$ NMR spectrum. The HRESIMS analysis demonstrated that they had the same molecular formula of $\mathrm{C}_{15} \mathrm{H}_{24} \mathrm{O}_{3}(\mathrm{~m} / \mathrm{z}$ 275.1621 $[\mathrm{M}+\mathrm{Na}]^{+}$, calcd for 275.1618). The doubled signals in the ${ }^{1} \mathrm{H}$ and ${ }^{13} \mathrm{C}$ NMR spectra and similar proton peak types indicated that the two compounds were epimers. The 1D NMR spectra of the mixture showed signals which were categorized into three methyls, four methylenes (one oxygenated), five methines (two oxygenated), and three quaternary carbons (two olefinic) (Tables 2, 4). The data showed a resemblance to those of ceriponol $\mathrm{G}$ [12], except an absence of a methoxy signal at C-12. Thus, the planar structures of $\mathbf{6}$ and $\mathbf{7}$ were elucidated as shown in Fig. 2. The inseparable feature of $\mathbf{6}$ and $\mathbf{7}$ implied that they were semiacetal tautomers. The 12-OH of 6 and 7 were assigned as $\alpha$ and $\beta$ orientation, respectively, by the key ROESY cross peaks between $\mathrm{H}-3\left(\delta_{\mathrm{H}} 2.54\right) / \mathrm{H}-12\left(\delta_{\mathrm{H}}\right.$ $5.23)$ of $\mathbf{6}$, and the absence of ROESY signals between $\mathrm{H}-3\left(\delta_{\mathrm{H}} 2.27\right)$ and $\mathrm{H}-12\left(\delta_{\mathrm{H}} 4.74\right)$ of 7 (Fig. 4$)$. The 5-OH of 6 and 7 were $\alpha$ orientation as suggested by the ROESY correlations between $\mathrm{H}_{3}-13 / \mathrm{H}-5$ (Fig. 4). Therefore, compounds 6 and 7 were identified as irpexolactins $\mathrm{E}$ and $\mathrm{F}$.

The colorless oil of compound $\mathbf{8}$ possessed a molecular formula of $\mathrm{C}_{15} \mathrm{H}_{22} \mathrm{O}_{3}$, suggested by HRESIMS analysis $\left(m / z, 273.1468[\mathrm{M}+\mathrm{Na}]^{+}\right.$, calcd for $\mathrm{C}_{15} \mathrm{H}_{22} \mathrm{O}_{3} \mathrm{Na}$, 273.1461). The ${ }^{1} \mathrm{H}$ and ${ }^{13} \mathrm{C}$ NMR data of 8 (Tables 2, 4) are similar to those of $\mathbf{6 / 7}$, suggesting that 8 is congener of $6 / 7$. Elucidating the 2D NMR spectra of 8 suggested that $\mathrm{C}-12$ in $\mathbf{8}$ was substituted by a carbonyl as supported by the HMBC correlations from $\mathrm{H}-4\left(\delta_{\mathrm{H}} 2.00\right.$ and 1.84$)$ and $\mathrm{H}-11\left(\delta_{\mathrm{H}} 4.80\right.$ and 4.72$)$ to $\mathrm{C}-12\left(\delta_{\mathrm{C}} 182.6\right)$. The relative configuration of 8 was consistent with that of $6 / 7$ by the ROESY analysis. Thus, the chemical structure of 
Table $2{ }^{1} \mathrm{H}$ NMR spectroscopic data of compounds 6-11 (600 MHz, $\delta$ in ppm)

\begin{tabular}{|c|c|c|c|c|c|c|}
\hline $\mathrm{No}$ & $6^{\mathrm{a}}$ & $7^{\mathrm{a}}$ & $8^{\mathrm{a}}$ & $9^{a}$ & $10^{b}$ & $11^{\mathrm{b}}$ \\
\hline 1 & & & & $\begin{array}{l}\text { 2.84, ddd (13.3, } \\
13.3,10.5)\end{array}$ & $\begin{array}{l}\text { 2.78, ddd (13.3, } \\
13.3,10.5)\end{array}$ & $\begin{array}{l}2.76, \text { ddd }(13.3,13.3 \text {, } \\
10.5)\end{array}$ \\
\hline 3 & $2.54, \mathrm{~m}$ & $2.27, \mathrm{~m}$ & 3.64 , br d (12.9) & & & \\
\hline 4 & $\begin{array}{l}\text { 1.98, br dd }(13.5 \text {, } \\
\text { 6.3) } \\
1.83 \text {, ddd }(13.5 \\
13.5,10.6)\end{array}$ & $\begin{array}{l}2.08, \mathrm{~m} \\
1.71, \mathrm{ddd}(13.5, \\
13.5,10.6)\end{array}$ & $\begin{array}{l}2.00, \text { ddd }(14.2,5.0, \\
2.8) \\
1.84, \text { ddd }(14.2, \\
12.9,2.0)\end{array}$ & $\begin{array}{l}2.53, \text { ddd }(17.2,8.1 \text {, } \\
2.5) \\
2.20, \text { ddd }(17.2, \\
10.6,2.6)\end{array}$ & $\begin{array}{l}\text { 2.52, br d (17.0) } \\
2.32, \text { br dd (17.0, } \\
2.6)\end{array}$ & $\begin{array}{l}2.51, \text { ddd }(17.0,4.0 \text {, } \\
4.0) \\
\text { 2.33, ddd }(17.0,12.0 \text {, } \\
4.0)\end{array}$ \\
\hline 5 & $3.75, \mathrm{dd}(10.6,5.0)$ & 3.74, dd $(10.6,5.0)$ & $\begin{array}{l}\text { 3.97, ddd (5.0, 5.0, } \\
2.0)\end{array}$ & $\begin{array}{l}1.88, \text { ddd }(14.0,8.1 \text {, } \\
2.6) \\
1.69, \text { ddd }(14.0, \\
10.6,2.5)\end{array}$ & $\begin{array}{l}1.75, \mathrm{~m} \\
1.68, \mathrm{~m}\end{array}$ & $\begin{array}{l}1.74, \mathrm{~m} \\
1.68, \mathrm{~m}\end{array}$ \\
\hline 6 & $1.93, \mathrm{~m}$ & $1.93, \mathrm{~m}$ & $1.87, \mathrm{~m}$ & & 2.15 , overlapped & 2.16 , overlapped \\
\hline 7 & $3.38, \mathrm{~m}$ & $3.37, \mathrm{~m}$ & $3.45, \mathrm{~m}$ & $\begin{array}{l}\text { 2.25, ddd (10.5, } \\
10.5,8.6)\end{array}$ & 2.13 , overlapped & 2.13 , overlapped \\
\hline 8 & $\begin{array}{l}1.47, \mathrm{dd}(12.3,1.6) \\
1.44, \mathrm{~d}(12.3)\end{array}$ & $\begin{array}{l}1.47, \mathrm{dd}(12.3,1.6) \\
1.44, \mathrm{~d}(12.3)\end{array}$ & $\begin{array}{l}1.52, \mathrm{dd}(13.6,12.1) \\
1.48, \mathrm{~d}(13.6)\end{array}$ & $\begin{array}{l}1.73, \mathrm{dd}(13.0,8.6) \\
1.58, \mathrm{dd}(13.0,10.5)\end{array}$ & $\begin{array}{l}\text { 1.56, overlapped } \\
1.45, \text { dd }(13.0,7.5)\end{array}$ & $\begin{array}{l}1.55, \mathrm{dd}(12.7,12.7) \\
1.39, \mathrm{dd}(12.7,7.1)\end{array}$ \\
\hline \multicolumn{7}{|l|}{9} \\
\hline 10 & $\begin{array}{l}2.04, \text { overlapped } \\
1.92, \text { overlapped }\end{array}$ & $\begin{array}{l}2.05, \text { overlapped } \\
1.89, \text { overlapped }\end{array}$ & 1.93, br s & $\begin{array}{l}1.82, \mathrm{dd}(12.2,7.6) \\
1.50, \mathrm{dd}(12.2,12.2)\end{array}$ & $\begin{array}{l}1.97, \mathrm{dd}(12.7,7.7) \\
1.33, \mathrm{dd}(12.2,12.2)\end{array}$ & $\begin{array}{l}2.02, \mathrm{dd}(12.2,7.6) \\
1.27, \mathrm{dd}(12.2,12.2)\end{array}$ \\
\hline 11 & $\begin{array}{l}4.39 \text {, ddd (13.0, 5.0, } \\
2.5) \\
4.18 \text {, ddd (13.0, 3.6, } \\
2.2)\end{array}$ & $\begin{array}{l}\text { 4.32, ddd }(13.0,3.5 \text {, } \\
2.0) \\
4.20 \text {, ddd }(13.0,4.5 \text {, } \\
2.5)\end{array}$ & $\begin{array}{l}4.80, \text { br d (13.5) } \\
4.72 \text {, br d }(13.5)\end{array}$ & $\begin{array}{l}4.77, \mathrm{~d}(18.0) \\
4.70, \mathrm{~d}(18.0)\end{array}$ & $\begin{array}{l}4.63, \text { br d (17.0) } \\
4.56, \text { br d }(17.0)\end{array}$ & $\begin{array}{l}4.64, \mathrm{~d}(16.9) \\
4.56, \mathrm{~d}(16.9)\end{array}$ \\
\hline 12 & $5.23, \mathrm{~d}(5.0)$ & $4.74, \mathrm{~d}(7.4)$ & & & & \\
\hline 13 & $0.91, \mathrm{~d}(7.6)$ & $0.92, \mathrm{~d}(7.6)$ & $0.88, \mathrm{~d}(7.0)$ & $1.24, \mathrm{~s}$ & $0.95, \mathrm{~d}(7.6)$ & $0.95, \mathrm{~d}(7.0)$ \\
\hline 14 & $1.09, \mathrm{~s}$ & $1.09, \mathrm{~s}$ & $0.91, \mathrm{~s}$ & $1.09, \mathrm{~s}$ & $1.11, \mathrm{~s}$ & $1.09, \mathrm{~s}$ \\
\hline 15 & $1.05, \mathrm{~s}$ & $1.03, \mathrm{~s}$ & $1.13, \mathrm{~s}$ & $1.08, \mathrm{~s}$ & $\begin{array}{l}3.87, \mathrm{~d}(10.5) \\
3.81, \mathrm{~d}(10.5)\end{array}$ & $\begin{array}{l}3.40, \mathrm{~d}(10.7) \\
3.37, \mathrm{~d}(10.7)\end{array}$ \\
\hline $\mathrm{AcO}-$ & & & & & $2.09, \mathrm{~s}$ & \\
\hline
\end{tabular}

${ }^{\mathrm{a}}$ Recorded in $\mathrm{CD}_{3} \mathrm{OD}$

${ }^{\mathrm{b}}$ Recorded in $\mathrm{CDCl}_{3}$

compound $\mathbf{8}$ was established as shown in Fig. 1 and the name irpexolactin $\mathrm{G}$.

Irpexolactin $\mathrm{H}(\mathbf{9})$ was isolated as a colorless oil. The 1D NMR spectra (Tables 2, 5) displayed three methyl singlets, five methylenes (one oxygenated), two methines, and five quaternary carbons (two $\mathrm{sp}^{3}$ ones, and three $\mathrm{sp}^{2}$ ones). The 1D NMR data of 9 showed similarity with those of ceriponol C [12], indicating they were structurally related. Interpreting of the 2D NMR spectra of 9 suggested that the hydroxy group was substituted at C-6 in 9 instead of C-8 in ceriponol C, which supported by HMBC correlations from $\mathrm{H}_{3}-13\left(\delta_{\mathrm{H}}\right.$ $1.24)$ to $\mathrm{C}-5\left(\delta_{\mathrm{C}} 43.0\right), \mathrm{C}-6\left(\delta_{\mathrm{C}} 75.0\right)$, and C-7 $\left(\delta_{\mathrm{C}} 55.7\right)$, from $\mathrm{H}-4\left(\delta_{\mathrm{H}} 2.53\right.$ and 2.20$)$ and $\mathrm{H}-8\left(\delta_{\mathrm{H}} 1.73\right.$ and 1.58$)$ to $\mathrm{C}-6$. The relative configuration of $\mathrm{H}-1,6-\mathrm{OH}, \mathrm{H}-7$ were assigned as $\beta, \alpha, \alpha$, respectively, based on the ROESY signals of $\mathrm{H}-1$ $\left(\delta_{\mathrm{H}} 2.84\right) / \mathrm{H}_{3}-13 / \mathrm{H}-8 \beta\left(\delta_{\mathrm{H}} 1.58\right)$, and H-7 $\left(\delta_{\mathrm{H}} 2.25\right) / \mathrm{H}-8 \alpha\left(\delta_{\mathrm{H}}\right.$ 1.73) (Fig. 4). All these assignments led to the establishment of the structure of 9 as shown in Fig. 3, which was consistent with the HRESIMS results $\left(m / z 273.1465[\mathrm{M}+\mathrm{Na}]^{+}\right.$, calcd for $\mathrm{C}_{15} \mathrm{H}_{22} \mathrm{O}_{3} \mathrm{Na}, 273.1461$ ). Thus, compound 9 was identified as $6 \alpha$-hydroxy-tremul-2-en-12,11-olide.

The oily compounds irpexolactins I (10) and J (11) were determined to possess the molecular formulas of $\mathrm{C}_{17} \mathrm{H}_{24} \mathrm{O}_{4}$ and $\mathrm{C}_{15} \mathrm{H}_{22} \mathrm{O}_{3}$, respectively. The $1 \mathrm{D} \mathrm{NMR}$ data of $\mathbf{1 0}$ (Tables 2, 5) resembled to those of the co-isolate tremulenolide D (17) [13], with the main difference located at C-14. The HMBC correlations from $\mathrm{H}_{3}-14\left(\delta_{\mathrm{H}} 1.11\right.$ for $\mathbf{1 0}, 1.09$ for 11) to C-15 $\left(\delta_{\mathrm{C}} 72.2\right.$ for $\mathbf{1 0}, 71.4$ for 11$)$, from $\mathrm{H}-15\left(\delta_{\mathrm{H}} 3.87\right.$, 3.81 for 10) and a methyl singlet at $\delta_{\mathrm{H}} 2.09$ to a carbonyl at $\delta_{\mathrm{C}} 171.5$ suggested that $\mathrm{H}_{3}-15$ in tremulenolide D (17) was oxygenated into a hydroxymethyl to give 11, which was further acetylated to yield $\mathbf{1 0}$ (Fig. 1). The oxygen-bearing $\mathrm{C}-15$ was assigned as $\beta$ orientation which evidenced by the ROESY correlation between $\mathrm{H}-15\left(\delta_{\mathrm{H}} 3.87,3.81\right.$ for $\mathbf{1 0}$, $3.40,3.37$ for 11) and $\mathrm{H}-1\left(\delta_{\mathrm{H}} 2.78\right.$ for $\mathbf{1 0}, 2.76$ for 11) (Fig. 4), and the relative configurations of Me-13 and $\mathrm{H}-7$ were identical with those of compound $\mathbf{9}$. Therefore, the structures of $\mathbf{1 0}$ and $\mathbf{1 1}$ were established as shown in Fig. 1. 
Table $3{ }^{1} \mathrm{H}$ NMR spectroscopic data of compounds 12-15 (600 MHz, $\delta$ in ppm)

\begin{tabular}{|c|c|c|c|c|}
\hline No & $12^{\mathrm{a}}$ & $13^{\mathrm{b}}$ & $14^{\mathrm{a}}$ & $15^{\mathrm{a}}$ \\
\hline 3 & $2.80, \mathrm{~m}$ & $2.74, \mathrm{~m}$ & $2.57, \mathrm{~m}$ & $2.79, \mathrm{~m}$ \\
\hline 4 & 4.02, overlapped & $\begin{array}{l}1.80, \text { ddd }(14.2,2.6,2.6) \\
1.64, \text { overlapped }\end{array}$ & $\begin{array}{l}1.81 \text {, overlapped } \\
1.75 \text {, overlapped }\end{array}$ & $\begin{array}{l}1.85, \mathrm{~m} \\
1.72, \text { overlapped }\end{array}$ \\
\hline 5 & $\begin{array}{l}1.98, \text { ddd }(12.7,12.7,3.5) \\
1.85, \text { overlapped }\end{array}$ & $\begin{array}{l}1.89, \text { ddd }(13.8,3.0,3.0) \\
1.61, \text { overlapped }\end{array}$ & $\begin{array}{l}1.78, \text { overlapped } \\
1.62, \mathrm{~m}\end{array}$ & $\begin{array}{l}1.95 \text {, overlapped } \\
1.74, \text { overlapped }\end{array}$ \\
\hline 6 & 1.88 , overlapped & $1.77, \mathrm{~m}$ & $1.96, \mathrm{~m}$ & \\
\hline 7 & 3.07, br dd $(11.3,8.9)$ & 3.04, br dd $(9.8,9.8)$ & 3.10, br dd $(11.7,8.5)$ & 3.09, dd $(9.6,9.6)$ \\
\hline 8 & $\begin{array}{l}1.55, \mathrm{dd}(12.3,8.9) \\
1.42, \mathrm{dd}(12.3,11.3)\end{array}$ & $\begin{array}{l}\text { 1.51, overlapped } \\
1.38 \text {, dd }(12.8,11.8)\end{array}$ & $\begin{array}{l}1.55, \mathrm{dd}(11.7,11.7) \\
1.43, \mathrm{dd}(11.7,8.5)\end{array}$ & $\begin{array}{l}\text { 1.65, br dd }(13.2,8.3) \\
1.57, \operatorname{dd}(13.2,10.7)\end{array}$ \\
\hline 10 & $\begin{array}{l}2.31, \mathrm{~d}(15.3) \\
1.93, \mathrm{~d}(15.3)\end{array}$ & $\begin{array}{l}2.24, \mathrm{~d}(15.1) \\
1.91, \mathrm{~d}(15.1)\end{array}$ & $\begin{array}{l}2.21, \text { br d (15.2) } \\
2.06, \text { br d }(15.2)\end{array}$ & $\begin{array}{l}2.31, \mathrm{~d}(14.8) \\
1.97, \mathrm{~d}(14.8)\end{array}$ \\
\hline 11 & $\begin{array}{l}4.11, \mathrm{~d}(11.3) \\
3.93, \mathrm{~d}(11.3)\end{array}$ & $\begin{array}{l}4.11, \mathrm{dd}(11.6,6.5) \\
4.01, \mathrm{dd}(11.6,4.5)\end{array}$ & $\begin{array}{l}4.06, \mathrm{~d}(11.3) \\
3.95, \mathrm{~d}(11.3)\end{array}$ & $\begin{array}{l}4.03, \mathrm{~d}(12.0) \\
4.00, \mathrm{~d}(12.0)\end{array}$ \\
\hline 12 & $\begin{array}{l}\text { 4.01, overlapped } \\
3.84, \text { dd }(9.2,9.2)\end{array}$ & $\begin{array}{l}4.29 \text {, dd }(10.5,7.4) \\
4.23 \text {, dd }(10.5,8.9)\end{array}$ & $\begin{array}{l}3.73, \mathrm{dd}(10.5,9.0) \\
3.70, \mathrm{dd}(10.5,7.4)\end{array}$ & $\begin{array}{l}4.34, \mathrm{dd}(10.7,10.7) \\
4.19, \mathrm{dd}(10.7,5.7)\end{array}$ \\
\hline 13 & $0.92, \mathrm{~d}(7.0)$ & $0.82, \mathrm{~d}(7.0)$ & $0.87, \mathrm{~d}(7.0)$ & $1.08, \mathrm{~s}$ \\
\hline 14 & $1.08, \mathrm{~s}$ & $1.06, \mathrm{~s}$ & $0.89, \mathrm{~s}$ & $1.10, \mathrm{~s}$ \\
\hline 15 & $0.88, \mathrm{~s}$ & $0.83, \mathrm{~s}$ & $\begin{array}{l}3.38, \mathrm{~d}(10.0) \\
3.40, \mathrm{~d}(10.0)\end{array}$ & $0.86, \mathrm{~s}$ \\
\hline OAc & & $2.06, \mathrm{~s}$ & & $2.04, \mathrm{~s}$ \\
\hline $11-\mathrm{OH}$ & & $1.54, \mathrm{dd}(6.5,4.5)$ & & \\
\hline
\end{tabular}

${ }^{\mathrm{a}}$ Recorded in $\mathrm{CD}_{3} \mathrm{OD}$

${ }^{\mathrm{b}}$ Recorded in $\mathrm{CDCl}_{3}$

Table $4{ }^{13} \mathrm{C}$ NMR spectroscopic data of compounds 1-8 $(150 \mathrm{MHz}, \delta$ in ppm)

\begin{tabular}{|c|c|c|c|c|c|c|c|c|}
\hline No & $\mathbf{1}^{\mathrm{a}}$ & $2^{\mathrm{a}}$ & $3^{b}$ & $4^{c}$ & $\mathbf{5}^{\mathrm{a}}$ & $6^{\mathrm{a}, \mathrm{d}}$ & $7^{\mathrm{a}, \mathrm{d}}$ & $8^{\mathrm{a}}$ \\
\hline 1 & $133.1, \mathrm{C}$ & $37.8, \mathrm{CH}$ & $170.1, \mathrm{C}$ & 93.7, C & 143.3, C & $135.39, \mathrm{C}$ & 136.07, C & $140.6, \mathrm{C}$ \\
\hline 2 & $134.5, \mathrm{C}$ & $145.5, \mathrm{C}$ & $123.3, \mathrm{C}$ & 156.1, C & 137.9, C & $131.28, \mathrm{C}$ & $131.65, \mathrm{C}$ & $126.8, \mathrm{C}$ \\
\hline 3 & $46.3, \mathrm{CH}$ & $139.4, \mathrm{C}$ & 74.4, C & $52.2, \mathrm{CH}$ & $41.1, \mathrm{CH}$ & $45.15, \mathrm{CH}$ & $47.04, \mathrm{CH}$ & $38.8, \mathrm{CH}$ \\
\hline 4 & $31.4, \mathrm{CH}_{2}$ & $29.5, \mathrm{CH}_{2}$ & $26.8, \mathrm{CH}_{2}$ & 26.7, $\mathrm{CH}_{2}$ & $38.4, \mathrm{CH}_{2}$ & $34.39, \mathrm{CH}_{2}$ & $35.81, \mathrm{CH}_{2}$ & $31.1, \mathrm{CH}_{2}$ \\
\hline 5 & $80.0, \mathrm{CH}$ & 74.7, $\mathrm{CH}$ & $30.1, \mathrm{CH}_{2}$ & 29.4, $\mathrm{CH}_{2}$ & $112.8, \mathrm{C}$ & $76.79, \mathrm{CH}$ & $76.48, \mathrm{CH}$ & 73.6, CH \\
\hline 6 & $44.4, \mathrm{C}$ & 41.6, CH & $32.4, \mathrm{CH}$ & $32.1, \mathrm{CH}$ & 43.7, $\mathrm{CH}$ & $45.05, \mathrm{CH}$ & $44.91, \mathrm{CH}$ & $39.7, \mathrm{CH}$ \\
\hline 7 & $71.4, \mathrm{CH}$ & 43.6, $\mathrm{CH}$ & $48.0, \mathrm{CH}$ & $51.3, \mathrm{CH}$ & $42.9, \mathrm{CH}$ & $40.64, \mathrm{CH}$ & $40.73, \mathrm{CH}$ & $41.2, \mathrm{CH}$ \\
\hline 8 & $44.3, \mathrm{CH}_{2}$ & $45.2, \mathrm{CH}_{2}$ & $43.8, \mathrm{CH}_{2}$ & 37.6, $\mathrm{CH}_{2}$ & $45.4, \mathrm{CH}_{2}$ & $47.10, \mathrm{CH}_{2}$ & $47.19, \mathrm{CH}_{2}$ & $45.5, \mathrm{CH}_{2}$ \\
\hline 9 & $33.4, \mathrm{C}$ & $37.3, \mathrm{C}$ & $38.9, \mathrm{C}$ & $41.5, \mathrm{C}$ & $38.4, \mathrm{C}$ & $38.59, \mathrm{C}$ & $38.46, \mathrm{C}$ & $39.6, \mathrm{C}$ \\
\hline 10 & $39.5, \mathrm{CH}_{2}$ & $47.2, \mathrm{CH}_{2}$ & $49.2, \mathrm{CH}_{2}$ & $48.9, \mathrm{CH}_{2}$ & 48.6, $\mathrm{CH}_{2}$ & $47.22, \mathrm{CH}_{2}$ & $47.96, \mathrm{CH}_{2}$ & $47.4, \mathrm{CH}_{2}$ \\
\hline 11 & $68.2, \mathrm{CH}_{2}$ & $172.7, \mathrm{C}$ & 168.6, C & 107.1, $\mathrm{CH}_{2}$ & $65.3, \mathrm{CH}_{2}$ & $69.53, \mathrm{CH}_{2}$ & $68.56, \mathrm{CH}_{2}$ & 70.9, $\mathrm{CH}_{2}$ \\
\hline 12 & $111.3, \mathrm{CH}$ & $173.2, \mathrm{C}$ & $179.8, \mathrm{C}$ & $106.2, \mathrm{CH}$ & 75.1, $\mathrm{CH}_{2}$ & $100.99, \mathrm{CH}$ & $104.78, \mathrm{CH}$ & 182.6, C \\
\hline 13 & $18.0, \mathrm{CH}_{3}$ & 12.6, $\mathrm{CH}_{3}$ & 11.6, $\mathrm{CH}_{3}$ & $14.7, \mathrm{CH}_{3}$ & $12.7, \mathrm{CH}_{3}$ & $14.96, \mathrm{CH}_{3}$ & $14.81, \mathrm{CH}_{3}$ & $12.1, \mathrm{CH}_{3}$ \\
\hline 14 & 25.6, $\mathrm{CH}_{3}$ & $32.0, \mathrm{CH}_{3}$ & 27.3, $\mathrm{CH}_{3}$ & $26.1, \mathrm{CH}_{3}$ & $29.3, \mathrm{CH}_{3}$ & $29.78, \mathrm{CH}_{3}$ & $29.70, \mathrm{CH}_{3}$ & 27.5, $\mathrm{CH}_{3}$ \\
\hline 15 & $32.5, \mathrm{CH}_{3}$ & $31.6, \mathrm{CH}_{3}$ & $28.5, \mathrm{CH}_{3}$ & $71.1, \mathrm{CH}_{2}$ & $27.3, \mathrm{CH}_{3}$ & $28.24, \mathrm{CH}_{3}$ & $28.16, \mathrm{CH}_{3}$ & $29.0, \mathrm{CH}_{3}$ \\
\hline $1^{\prime}$ & & $41.3, \mathrm{CH}_{2}$ & $41.5, \mathrm{CH}_{2}$ & & & & & \\
\hline $2^{\prime}$ & & $60.4, \mathrm{CH}_{2}$ & $61.0, \mathrm{CH}_{2}$ & & & & & \\
\hline $\mathrm{MeO}$ & $56.8, \mathrm{CH}_{3}$ & & & $53.6, \mathrm{OCH}_{3}$ & & & & \\
\hline
\end{tabular}

${ }^{\mathrm{a}}$ Recorded in $\mathrm{CD}_{3} \mathrm{OD}$

${ }^{\mathrm{b}}$ Recorded in $\mathrm{CDCl}_{3}$

${ }^{\mathrm{c}}$ Recorded in acetone- $d_{6}$

${ }^{\mathrm{d}}$ Assignments were rounded to two decimal places to tell apart the close resonances 
Table $5{ }^{13}$ C NMR spectroscopic data of compounds 9-15 $(150 \mathrm{MHz}, \delta$ in ppm)

\begin{tabular}{|c|c|c|c|c|c|c|c|}
\hline No & $9^{a}$ & $10^{\mathrm{b}}$ & $11^{\mathrm{b}}$ & $12^{\mathrm{a}}$ & $13^{\mathrm{b}}$ & $14^{\mathrm{a}}$ & $15^{\mathrm{a}}$ \\
\hline 1 & $41.3, \mathrm{CH}$ & $40.4, \mathrm{CH}$ & $39.1, \mathrm{CH}$ & $146.9, \mathrm{C}$ & 146.1, C & $144.8, \mathrm{C}$ & 145.0, C \\
\hline 2 & 168.1, C & $163.1, \mathrm{C}$ & $163.5, \mathrm{C}$ & 131.1, C & $131.4, \mathrm{C}$ & $134.3, \mathrm{C}$ & $133.9, \mathrm{C}$ \\
\hline 3 & $127.9, \mathrm{C}$ & $128.1, \mathrm{C}$ & $127.9, \mathrm{C}$ & $52.8, \mathrm{CH}$ & $40.7, \mathrm{CH}$ & $45.8, \mathrm{CH}$ & $40.3, \mathrm{CH}$ \\
\hline 4 & 20.3, $\mathrm{CH}_{2}$ & $19.9, \mathrm{CH}_{2}$ & $20.0, \mathrm{CH}_{2}$ & $67.5, \mathrm{CH}$ & $21.5, \mathrm{CH}_{2}$ & $22.2, \mathrm{CH}_{2}$ & $25.4, \mathrm{CH}_{2}$ \\
\hline 5 & 43.0, $\mathrm{CH}_{2}$ & $32.1, \mathrm{CH}_{2}$ & $33.5, \mathrm{CH}_{2}$ & $42.6, \mathrm{CH}_{2}$ & $31.9, \mathrm{CH}_{2}$ & $33.2, \mathrm{CH}_{2}$ & $42.2, \mathrm{CH}_{2}$ \\
\hline 6 & 75.0, C & $33.4, \mathrm{CH}$ & $32.2, \mathrm{CH}$ & $33.9, \mathrm{CH}$ & $31.4, \mathrm{CH}$ & $33.3, \mathrm{CH}$ & 73.3, C \\
\hline 7 & $55.7, \mathrm{CH}$ & 48.6, $\mathrm{CH}$ & 48.6, CH & $46.6, \mathrm{CH}$ & $46.2, \mathrm{CH}$ & $47.1, \mathrm{CH}$ & $53.5, \mathrm{CH}$ \\
\hline 8 & $42.9, \mathrm{CH}_{2}$ & $39.78, \mathrm{CH}_{2}{ }^{\mathrm{c}}$ & $40.1, \mathrm{CH}_{2}$ & $46.5, \mathrm{CH}_{2}$ & $45.3, \mathrm{CH}_{2}$ & $41.4, \mathrm{CH}_{2}$ & $44.0, \mathrm{CH}_{2}$ \\
\hline 9 & $37.3, \mathrm{C}$ & $39.84, \mathrm{C}^{c}$ & 41.6, C & $38.2, \mathrm{C}$ & $37.1, \mathrm{C}$ & $43.7, \mathrm{C}$ & $37.1, \mathrm{C}$ \\
\hline 10 & $45.1, \mathrm{CH}_{2}$ & $39.0, \mathrm{CH}_{2}$ & $39.2, \mathrm{CH}_{2}$ & $48.7, \mathrm{CH}_{2}$ & $47.8, \mathrm{CH}_{2}$ & $43.8, \mathrm{CH}_{2}$ & $48.1, \mathrm{CH}_{2}$ \\
\hline 11 & $72.3, \mathrm{CH}_{2}$ & $70.5, \mathrm{CH}_{2}$ & $70.6, \mathrm{CH}_{2}$ & $66.1, \mathrm{CH}_{2}$ & 66.3, $\mathrm{CH}_{2}$ & $66.2, \mathrm{CH}_{2}$ & 66.1. $\mathrm{CH}_{2}$ \\
\hline 12 & 177.6, C & $175.4, \mathrm{C}$ & 175.5, C & $60.2, \mathrm{CH}_{2}$ & $63.7, \mathrm{CH}_{2}$ & $61.8, \mathrm{CH}_{2}$ & $63.9, \mathrm{CH}_{2}$ \\
\hline 13 & $21.1, \mathrm{CH}_{3}$ & $11.5, \mathrm{CH}_{3}$ & 11.6, $\mathrm{CH}_{3}$ & $12.9, \mathrm{CH}_{3}$ & $11.6, \mathrm{CH}_{3}$ & $12.1, \mathrm{CH}_{3}$ & $19.9, \mathrm{CH}_{3}$ \\
\hline 14 & $31.4, \mathrm{CH}_{3}$ & $26.9, \mathrm{CH}_{3}$ & $26.5, \mathrm{CH}_{3}$ & $29.0, \mathrm{CH}_{3}$ & $28.5, \mathrm{CH}_{3}$ & $22.8, \mathrm{CH}_{3}$ & $29.0, \mathrm{CH}_{3}$ \\
\hline 15 & $31.1, \mathrm{CH}_{3}$ & $72.2, \mathrm{CH}_{2}$ & 71.4, $\mathrm{CH}_{2}$ & $27.3, \mathrm{CH}_{3}$ & $26.8, \mathrm{CH}_{3}$ & 71.6, $\mathrm{CH}_{2}$ & 27.2, $\mathrm{CH}_{3}$ \\
\hline $\mathrm{CH}_{3} \mathrm{CO}-$ & & $171.5, \mathrm{C}$ & & & 171.1, C & & 173.1, C \\
\hline $\mathrm{CH}_{3} \mathrm{CO}-$ & & $21.2, \mathrm{CH}_{3}$ & & & $21.1, \mathrm{CH}_{3}$ & & $21.0, \mathrm{CH}_{3}$ \\
\hline
\end{tabular}

${ }^{a}$ Recorded in $\mathrm{CD}_{3} \mathrm{OD}$

${ }^{\mathrm{b}}$ Recorded in $\mathrm{CDCl}_{3}$

${ }^{\mathrm{c}}$ Assignments were rounded to two decimal places to tell apart the close resonances
Irpexolactin $\mathrm{K}(\mathbf{1 2})$ was obtained as a colorless oil. It was assigned the molecular formula of $\mathrm{C}_{15} \mathrm{H}_{26} \mathrm{O}_{3}$ on the basis of HRESIMS $\left(\mathrm{m} / z 277.1781[\mathrm{M}+\mathrm{Na}]^{+}\right.$, calcd for $\mathrm{C}_{15} \mathrm{H}_{26} \mathrm{O}_{3} \mathrm{Na}$, 277.1774). The NMR spectra of $\mathbf{1 2}$ (Tables 3, 5) exhibited similarities with those of the co-isolate tremulenediol A (18) [3]. The key difference was that a hydroxy group substituted at C-4 in $\mathbf{1 2}$ compared to $\mathbf{1 8}$, which in accordance with the chemical formula and further confirmed by 2D NMR spectra of 12. The ${ }^{1} \mathrm{H}-{ }^{1} \mathrm{H}$ COSY correlations between $\mathrm{H}-4\left(\delta_{\mathrm{H}} 4.02\right)$ and $\mathrm{H}-3\left(\delta_{\mathrm{H}} 2.80\right), \mathrm{H}-5\left(\delta_{\mathrm{H}} 1.98\right.$ and 1.85$)$, and $\mathrm{HMBC}$ correlation from $\mathrm{H}-12\left(\delta_{\mathrm{H}} 4.01,3.84\right)$ to $\mathrm{C}-2\left(\delta_{\mathrm{C}} 131.1\right), \mathrm{C}-3\left(\delta_{\mathrm{C}}\right.$ $52.8)$, and $\mathrm{C}-4\left(\delta_{\mathrm{C}} 67.5\right)$ corroborated the postulation. The relative configuration of 4-OH was determined as $\alpha$ based on the significant correlation between $\mathrm{H}-3 / \mathrm{H}-4$. Hence, compound 12 was determined as shown in Fig. 1.

The molecular formula of irpexolactin L (13) was assigned as $\mathrm{C}_{17} \mathrm{H}_{28} \mathrm{O}_{3}$ by HRESIMS $(\mathrm{m} / z, 303.1941$ $[\mathrm{M}+\mathrm{Na}]^{+}$, calcd for $\mathrm{C}_{17} \mathrm{H}_{28} \mathrm{O}_{3} \mathrm{Na}$, 303.1941), accounting for four degrees of unsaturation. The ${ }^{1} \mathrm{H}$ and ${ }^{13} \mathrm{C}$ NMR data of 13 (Tables 3, 5) showed features like those of tremulenediol A (18) [3], except the presence of an acetyl group $\left(\delta_{\mathrm{H}} 2.06\right.$; $\delta_{\mathrm{C}} 21.1$ and 171.1). The HMBC correlation from $\mathrm{H}-12\left(\delta_{\mathrm{H}}\right.$ 4.29 and 4.23) to carbonyl of acetyl group, suggesting an acetoxy group substituted at C-12. Therefore, compound $\mathbf{1 3}$ was elucidated as shown in Fig. 1.

Compound 14 was obtained as a colorless oil and found to possess the molecular formula of $\mathrm{C}_{15} \mathrm{H}_{26} \mathrm{O}_{3}$ based on HRESIMS data $\left(\mathrm{m} / \mathrm{z} 277.1778[\mathrm{M}+\mathrm{Na}]^{+}\right.$, calcd for $\left.\mathrm{C}_{15} \mathrm{H}_{26} \mathrm{O}_{3} \mathrm{Na}, 277.1774\right)$. The ${ }^{1} \mathrm{H}$ and ${ }^{13} \mathrm{C}$ NMR data of
14 (Tables 3, 5) were highly similar to those of conocenol A [11]. The most significant deviation of the ${ }^{13} \mathrm{C} N M R$ data between conocenol $\mathrm{A}$ and $\mathbf{1 4}$ located on the hydroxymethyl $\left(\delta_{\mathrm{C}} 68.7\right.$ for conocenol A (C-15), $\delta_{\mathrm{C}} 71.6$ for $\mathbf{1 4}$ (C-14)) which were recorded in the same deuterium solvent $\left(\mathrm{CD}_{3} \mathrm{OD}\right)$, implying the only difference involved in the configuration of hydroxymethyl group attached to C-9. The crucial ROESY correlations of $\mathrm{H}-7 / \mathrm{H}-8 \alpha, \mathrm{H}-15 \backslash \mathrm{H}-8 \beta$ helped to determine the $\beta$ orientation of $15-\mathrm{CH}_{2} \mathrm{OH}$, while it was $\alpha$ in conocenol A when its relative configuration was drawn as same as $\mathbf{1 4}$. Thus, compound $\mathbf{1 4}$ was established as irpexolactin $\mathrm{M}$.

Irpexolactin $\mathrm{N}(\mathbf{1 5})$, a colorless oil, showed a sodium adduct ion peak at $m / z 319.1871[\mathrm{M}+\mathrm{Na}]^{+}$in the HRESIMS spectrum, indicating the molecular formula of $\mathrm{C}_{17} \mathrm{H}_{28} \mathrm{O}_{4}$ (calcd for $\mathrm{C}_{17} \mathrm{H}_{28} \mathrm{O}_{4} \mathrm{Na}, 319.1880$ ). The 1D NMR (Tables 3, 5) spectra showed resonances of four methyl singlets, six methylenes (two oxygenated), two methines, and five quaternary carbons (Tables 3,5$)$. All these data showed similarity with those of $(+)-(3 S, 6 R, 7 R)$-tremulene-6,11,12-triol (19) [14]. The presence of an additional acetyl group $\left(\delta_{\mathrm{H}}\right.$ 2.04; $\delta_{\mathrm{C}} 21.0$ and 173.1) in $\mathbf{1 5}$ as well as the HMBC correlation from $\mathrm{H}-12\left(\delta_{\mathrm{H}} 4.34\right.$ and 4.19$)$ to the acetyl carbonyl indicated that the $12-\mathrm{OH}$ of $\mathbf{1 5}$ was acetylated compared to (+)-(3S,6R,7R)-tremulene-6,11,12-triol (19). Thus, compound 15 was identified as shown in Fig. 1.

The known sesquiterpenes were identified as conocenol C (16) [11], tremulenolide D (17) [13], tremulenediol A (18) [3], (+)- $(3 S, 6 R, 7 R)$-tremulene-6,11,12-triol (19) 
$[14,15]$, conocenol B (20) [11], (-)-(3S,6S,7S,10S)-tremulene-10,11,12-triol (21) [14, 15], irlactam A (22) [6], 11,12-dihydroxy-1-tremulen-5-one (23) [10], and irlactin A (24) [4].

The absolute configuration of conocenol B (20) was determined as $3 R, 5 R, 6 S, 7 R$ by single-crystal X-ray diffraction analysis (Fig. 5).

\subsection{Biological Activities}

Compounds $1,2,4,12$, and 22 were evaluated on vasorelaxant effect on $\mathrm{KCl}$ precontracted thoracic aorta rings. Nifedipine was used as the positive control. However, none of them showed significant vasorelaxant effect.

\section{Conclusions}

The chemical investigation on the culture broth of the medicinal fungus Irpex lacteus HFG1102 facilitated the isolation of 15 previously undescribed tremulane sesquiterpenes irlactin $\mathrm{K}(\mathbf{1})$, and irpexolactins A-N (2-15), and nine known ones, conocenol C (16), tremulenolide $\mathrm{D}(\mathbf{1 7})$, tremulenediol A (18), (+)-(3S,6R,7R)-tremulene-6,11,12-triol (19), conocenol B (20), (-)-(3S,6S,7S,10S)-tremulene-10,11,12-triol (21), irlactam A (22), 11,12-dihydroxy-1-tremulen-5-one (23), and irlactin A (24). Among the all isolates, irpexolactins A (2) and B (3) possessed an unusual 1-(2-hydroxyethyl)pyrrolidine-2,5-dione moiety. This research expands the structural diversity of mushroom derived tremulane-type sesquiterpenoids.

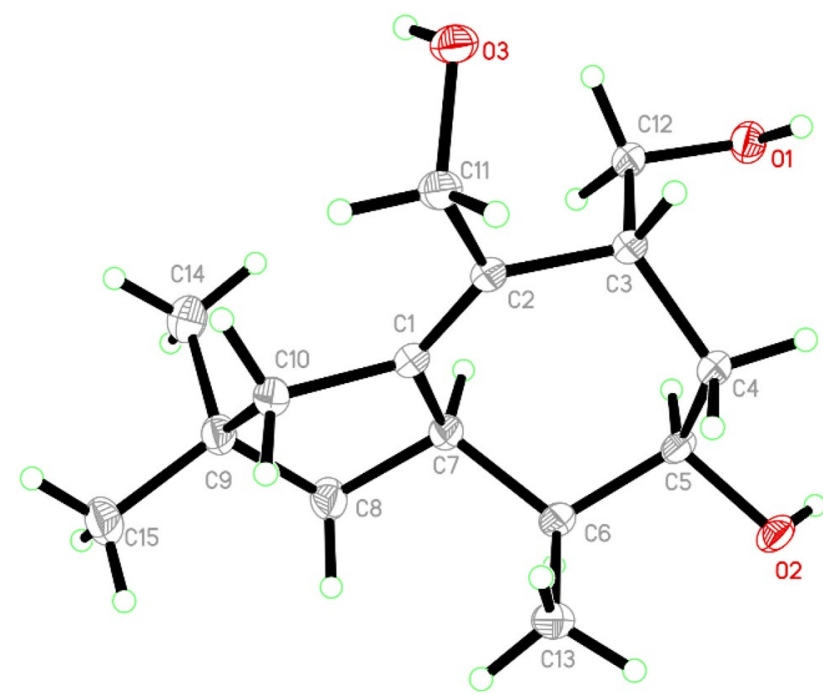

Fig. 5 ORTEP drawing of compound 20

\section{Experimental}

\subsection{General Experimental Procedures}

Optical rotations were obtained on a JASCO P-1020 digital polarimeter (Horiba, Kyoto, Japan). UV spectra were recorded on a Shimadzu UV-2401PC UV-visible recording spectrophotometer (Shimadzu, Kyoto, Japan). 1D and 2D NMR spectra were obtained on a Bruker Avance III $600 \mathrm{MHz}$ spectrometer (Bruker Corporation, Karlsruhe, Germany). HRESIMS were recorded on an Agilent 6200 Q-TOF MS system (Agilent Technologies, Santa Clara, CA, USA). HREIMS were recorded on a Waters Auto-Spec Premier P776 instrument (Waters, Milford, MA, USA). Single crystal X-ray diffraction was performed on Bruker APEX II DUO and D8 QUEST diffractometers (Bruker AXS GmbH, Karlsruhe, Germany). Sephadex LH-20 (Amersham Biosciences, Uppsala, Sweden) and silica gel (Qingdao Haiyang Chemical Co., Ltd) were used for column chromatography (CC). Medium Pressure Liquid Chromatography (MPLC) was performed on a Büchi Sepacore System equipped with pump manager C-615, pump modules C-605 and fraction collector C-660 (Büchi Labortechnik AG, Flawil, Switzerland), and columns packed with Chromatorex C-18 (dimensions $450 \mathrm{~mm} \times$ i.d. $14 \mathrm{~mm}$, particle size: $40-75 \mu \mathrm{m}$, Fuji Silysia Chemical Ltd., Kasugai, Japan). Preparative high performance liquid chromatography (prep. HPLC) were performed on an Agilent 1260 liquid chromatography system equipped with Zorbax SB-C18 columns (particle size $5 \mu \mathrm{m}$, dimensions $150 \mathrm{~mm} \times$ i.d. $9.4 \mathrm{~mm}$, flow rate $7 \mathrm{ml} \cdot \mathrm{min}^{-1}$, respectively) and a DAD detector (Agilent Technologies, Santa Clara, CA, USA).

\subsection{Fungal Material}

The fungus Irpex lacteus was collected from Changbai Mountain Nature Reserve in 2012, and was identified by Prof. Yu-Cheng Dai (Beijing Forestry University), an expert in mushroon taxonomy. The strain of I. lacteus in this study was isolated from the fresh fruiting bodies and kept on potato, dextrose, and agar (PDA) culture medium. A voucher specimen (No. CGBWSHFG1102) was deposited in the Herbarium of Kunming Institute of Botany, Chinese Academy of Sciences. The culture medium to ferment this fungus consisted of glucose (5\%), peptone from porcine meat $(0.15 \%)$, yeast powder $(0.5 \%), \mathrm{KH}_{2} \mathrm{PO}_{4}(0.05 \%)$ and $\mathrm{MgSO}_{4}(0.05 \%)$. Sixty Erlenmeyer flasks $(500 \mathrm{ml})$ each containing $350 \mathrm{ml}$ of above-mentioned culture medium were inoculated with I. lacteus strains, respectively. Fermentation were carried out on rotatory shakers at $25{ }^{\circ} \mathrm{C}$ and $150 \mathrm{rpm}$ for 25 days in dark environment. 


\subsection{Extraction and Isolation}

The culture broth (20 L) of I. lacteus HFG1 102 was filtered and concentrated to $3 \mathrm{~L}$ followed by partitioned between EtOAc and water for four times to give an EtOAc layer. Meanwhile, the mycelia were extracted by EtOH (95\%) for three times. The EtOAc layer together with the mycelium extract were concentrated under reduced pressure to afford a crude extract $(16.0 \mathrm{~g})$. This residue was separated by MPLC (ODS column) with $\mathrm{MeOH} / \mathrm{H}_{2} \mathrm{O}$ (from 0:100 to 100:0) to give sixteen main fractions (A-P).

Subfraction E was fractionated by Sephadex LH-20 CC $(\mathrm{MeOH})$ to afford five subfractions E1-E5. Compounds $\mathbf{1 2}$ $(1.5 \mathrm{mg}), \mathbf{1 3}(2.4 \mathrm{mg}), \mathbf{1 4}(2.0 \mathrm{mg})$ were purified from E1 to E5, respectively, by Sephadex LH-20 CC using acetone as a mobile phase. Subfraction $\mathrm{F}$ was fractionated and purified by repeatedly Sephadex LH-20 (MeOH or acetone) to give compounds $\mathbf{1 6}(1.2 \mathrm{mg}), \mathbf{1 7}(1.8 \mathrm{mg}), \mathbf{1 9}(3.0 \mathrm{mg}), \mathbf{2 0}$ (2.5 mg).

Subfraction $G$ was separated by Sephadex LH-20 $(\mathrm{MeOH})$ to give four subfractions G1-G4. G4 was further separated by Sephadex LH-20 (acetone) to give three subfractions G4a-G4c. Compounds $\mathbf{1 0}(0.9 \mathrm{mg})$ and $\mathbf{1 5}$ $(1.0 \mathrm{mg})$ were purified from G4a and G4b by prep-HPLC,

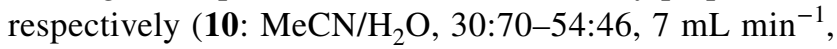
$\mathrm{t}_{\mathrm{R}}=18.5 \mathrm{~min} ; 15: \mathrm{MeCN} / \mathrm{H}_{2} \mathrm{O}, 25: 75-45: 55,7 \mathrm{~mL} \mathrm{~min}^{-1}$, $\mathrm{t}_{\mathrm{R}}=19.5 \mathrm{~min}$ ). Subfraction $\mathrm{G} 4 \mathrm{c}$ was purified by prep-HPLC $\left(\mathrm{MeCN} / \mathrm{H}_{2} \mathrm{O}, 28: 72-53: 47,7 \mathrm{~mL} \mathrm{~min}^{-1}\right.$ ) to give compounds $\mathbf{5 / 2 3}\left(\mathrm{t}_{\mathrm{R}}=5.0 \mathrm{~min}, 1.2 \mathrm{mg}\right), \mathbf{6} / 7\left(\mathrm{t}_{\mathrm{R}}=6.5 \mathrm{~min}, 2.2 \mathrm{mg}\right)$.

Subfraction $\mathrm{H}$ was separated by Sephadex LH-20 ( $\mathrm{MeOH})$ to give two subfractions $\mathrm{H} 1$ and $\mathrm{H} 2$. $\mathrm{H} 2$ was further separated by Sephadex LH-20 (acetone) to give three subfractions $\mathrm{H} 2 \mathrm{a}-\mathrm{H} 2 \mathrm{c}$. $\mathrm{H} 2 \mathrm{~b}$ was separated by silica gel CC to give seven subfractions H2b1-H2b7. Subfraction H2b2 was purified by prep-HPLC to yield compound $11(\mathrm{MeCN} /$ $\mathrm{H}_{2} \mathrm{O}, 18: 82-38: 62,7 \mathrm{~mL} \mathrm{~min}{ }^{-1}, \mathrm{t}_{\mathrm{R}}=17.5 \mathrm{~min}, 2.2 \mathrm{mg}$ ). Subfraction $\mathrm{H} 2 \mathrm{~b} 7$ was purified by prep-HPLC (MeCN/ $\mathrm{H}_{2} \mathrm{O}, 23: 77-43: 57,7 \mathrm{~mL} \mathrm{~min}^{-1}$ ) to yield compounds 2 $\left(\mathrm{t}_{\mathrm{R}}=10.5 \mathrm{~min}, 1.8 \mathrm{mg}\right), \mathbf{2 2}\left(\mathrm{t}_{\mathrm{R}}=14.8 \mathrm{~min}, 2.3 \mathrm{mg}\right)$, and $\mathbf{3}$ $\left(\mathrm{t}_{\mathrm{R}}=18.2 \mathrm{~min}, 1.5 \mathrm{mg}\right)$. and $21(2.5 \mathrm{mg})$.

Subfraction I was separated by Sephadex LH-20 (MeOH) to give two subfractions I1 and I2. Subfraction I1 was further separated by Sephadex LH-20 (acetone) and prep-HPLC ( $\mathrm{MeCN} / \mathrm{H}_{2} \mathrm{O}, 28: 72-48: 52,7 \mathrm{~mL} \mathrm{~min}^{-1}$ ) to give compound $\mathbf{8}\left(t_{R}=11.5 \mathrm{~min}, 3.2 \mathrm{mg}\right)$. Subfraction $\mathrm{I} 2$ was further purified by prep-HPLC $\left(\mathrm{MeCN} / \mathrm{H}_{2} \mathrm{O}, 30: 70-50: 50,7 \mathrm{~mL} \mathrm{~min}^{-1}\right)$ to give compound $4\left(t_{R}=14.5 \mathrm{~min}, 3.0 \mathrm{mg}\right)$.

Subfraction J was separated by Sephadex LH-20 $(\mathrm{MeOH})$ and further purified by prep-HPLC $(\mathrm{MeCN} /$ $\mathrm{H}_{2} \mathrm{O}, 18: 82-38: 62,7 \mathrm{~mL} \mathrm{~min}^{-1}$ ) to afford compound 9 $\left(\mathrm{t}_{\mathrm{R}}=13.3 \mathrm{~min}, 2.1 \mathrm{mg}\right)$.

Subfraction K was separated by Sephadex LH-20 $(\mathrm{MeOH})$ to give two main subfractions K1 and K2. Subfraction K1 was purified by prep-HPLC $\left(\mathrm{MeCN} / \mathrm{H}_{2} \mathrm{O}, 7: 93-27: 73\right.$, $\left.7 \mathrm{ml} \mathrm{min}{ }^{-1}\right)$ to afford compound $\mathbf{1 8}\left(\mathrm{t}_{\mathrm{R}}=14.3 \mathrm{~min}, 1.1 \mathrm{mg}\right)$ and $24\left(\mathrm{t}_{\mathrm{R}}=16.0 \mathrm{mg}, 1.5 \mathrm{mg}\right)$. Subfraction $\mathrm{K} 2$ was purified by prep-HPLC $\left(\mathrm{MeCN} / \mathrm{H}_{2} \mathrm{O}, 13: 87-33: 67,7 \mathrm{~mL} \mathrm{~min}^{-1}\right)$ to afford compound $\mathbf{1}\left(\mathrm{t}_{\mathrm{R}}=18.5 \mathrm{~min}, 0.9 \mathrm{mg}\right)$.

\subsection{Spectroscopic Data of Compounds}

\subsubsection{Irlactin K (1)}

Colorless needles; UV (MeOH) $\lambda_{\max } \mathrm{nm}(\log \varepsilon): 205$ (2.54); ${ }^{1} \mathrm{H}$ NMR $\left(600 \mathrm{MHz}, \mathrm{CDCl}_{3}\right.$ ) data, see Table $1 ;{ }^{13} \mathrm{C}$ NMR $\left(150 \mathrm{MHz}, \mathrm{CDCl}_{3}\right)$ data, see Table 4.

\subsubsection{Irpexolactin A (2)}

Pale-yellow oil; $[\alpha]_{\mathrm{D}}^{26}+79.2(c 0.07, \mathrm{MeOH})$. UV $(\mathrm{MeOH})$ $\lambda_{\text {max }} \mathrm{nm}(\log \varepsilon): 200$ (3.69), 231 (3.96); IR (KBr) $\nu_{\text {max }}$ 3426, 2927, 2859, 1701, 1632, 1406, $1030 \mathrm{~cm}^{-1}$; ${ }^{1} \mathrm{H}$ NMR $\left(600 \mathrm{MHz}, \mathrm{CDCl}_{3}\right)$ data, see Table $1 ;{ }^{13} \mathrm{C}$ NMR $(150 \mathrm{MHz}$, $\mathrm{CDCl}_{3}$ ) data, see Table 4; HRESIMS m/z 330.1685 $[\mathrm{M}+\mathrm{Na}]^{+}$(calcd for $\mathrm{C}_{17} \mathrm{H}_{25} \mathrm{NO}_{4} \mathrm{Na}, 330.1676$ ).

\subsubsection{Irpexolactin B (3)}

Colorless oil; $[\alpha]_{\mathrm{D}}^{26}+42.5($ c $0.10, \mathrm{MeOH}) .{ }^{1} \mathrm{H}$ NMR $\left(600 \mathrm{MHz}, \mathrm{CDCl}_{3}\right)$ data, see Table $1 ;{ }^{13} \mathrm{C}$ NMR $(150 \mathrm{MHz}$, $\mathrm{CDCl}_{3}$ ) data, see Table 4; HRESIMS $\mathrm{m} / \mathrm{z} 330.1687$ $[\mathrm{M}+\mathrm{Na}]^{+}$(calcd for $\mathrm{C}_{17} \mathrm{H}_{26} \mathrm{NO}_{4} \mathrm{Na}, 330.1676$ ).

\subsubsection{Irpexolactin C (4)}

Colorless oil; $[\alpha]_{\mathrm{D}}^{26}-95.9(c 0.07, \mathrm{MeOH}) . \mathrm{UV}(\mathrm{MeOH}) \lambda_{\max }$ nm (log $\varepsilon$ ): 204 (3.64); IR (KBr) $\nu_{\max } 3428,2926,2858$, 1632, 1384, $1031 \mathrm{~cm}^{-1} ;{ }^{1} \mathrm{H} \mathrm{NMR}\left(600 \mathrm{MHz}, \mathrm{CDCl}_{3}\right)$ data, see Table $1 ;{ }^{13} \mathrm{C}$ NMR $\left(150 \mathrm{MHz}, \mathrm{CDCl}_{3}\right)$ data, see Table 4; HRESIMS $m / z 289.1774[\mathrm{M}+\mathrm{Na}]^{+}\left(\right.$calcd for $\mathrm{C}_{16} \mathrm{H}_{26} \mathrm{O}_{3} \mathrm{Na}$, 289.1774).

\subsubsection{Irpexolactin D (5) and 23 Mixture}

Colorless oil; UV (MeOH) $\lambda_{\max } \mathrm{nm}(\log \varepsilon): 206$ (4.16), 244 (3.08); IR (KBr) $\nu_{\max } 3426,2951,2932,2870,1691,1631$, $1462,1383,1027 \mathrm{~cm}^{-1} ;{ }^{1} \mathrm{H}$ NMR $\left(600 \mathrm{MHz}, \mathrm{CDCl}_{3}\right)$ data, see Table $1 ;{ }^{13} \mathrm{C}$ NMR $\left(150 \mathrm{MHz}, \mathrm{CDCl}_{3}\right)$ data, see Table 4 ; HRESIMS $m / z 275.1624[\mathrm{M}+\mathrm{Na}]^{+}\left(\right.$calcd for $\mathrm{C}_{15} \mathrm{H}_{24} \mathrm{O}_{3} \mathrm{Na}$, 275.1618).

\subsubsection{Irpexolactins E\&F (6\&7)}

Yellow oil; UV (MeOH) $\lambda_{\max } \mathrm{nm}(\log \varepsilon): 206$ (3.66), 249 (3.36); IR (KBr) $\nu_{\max } 3426,2953,2928,2861,1632,1385$, $1029 \mathrm{~cm}^{-1}$; ${ }^{1} \mathrm{H}$ NMR $\left(600 \mathrm{MHz}, \mathrm{CDCl}_{3}\right)$ data, see Table 2; 
${ }^{13} \mathrm{C}$ NMR (150 MHz, $\mathrm{CDCl}_{3}$ ) data, see Table 4; HRESIMS $\mathrm{m} / \mathrm{z} 275.1621[\mathrm{M}+\mathrm{Na}]^{+}$(calcd for $\mathrm{C}_{15} \mathrm{H}_{24} \mathrm{O}_{3} \mathrm{Na}, 275.1618$ ).

\subsubsection{Irpexolactin G (8)}

Colorless oil; $[\alpha]_{\mathrm{D}}^{26}+17.1(c 0.06, \mathrm{MeOH}) . \mathrm{UV}(\mathrm{MeOH})$ $\lambda_{\max } \mathrm{nm}(\log \varepsilon): 207$ (3.66); IR (KBr) $\nu_{\max } 3421,2953$, 2928, 2869, 1755, 1629, 1381, 1171, $1029 \mathrm{~cm}^{-1}$; ${ }^{1} \mathrm{H}$ NMR $\left(600 \mathrm{MHz}, \mathrm{CDCl}_{3}\right)$ data, see Table $2 ;{ }^{13} \mathrm{C}$ NMR $(150 \mathrm{MHz}$, $\mathrm{CDCl}_{3}$ ) data, see Table 4; HRESIMS $\mathrm{m} / \mathrm{z} 273.1468$ $[\mathrm{M}+\mathrm{Na}]^{+}$(calcd for $\mathrm{C}_{15} \mathrm{H}_{22} \mathrm{O}_{3} \mathrm{Na}, 273.1461$ ).

\subsubsection{Irpexolactin $\mathrm{H}(9)$}

Colorless oil; $[\alpha]_{\mathrm{D}}^{26}+5.7($ c $0.14, \mathrm{MeOH}) . \mathrm{UV}(\mathrm{MeOH})$ $\lambda_{\max } \mathrm{nm}(\log \varepsilon): 219$ (3.71), 240.0 (3.27); IR (KBr) $\nu_{\max }$ 3424, 2928, 2859, 1726, 1631, 1384, $1029 \mathrm{~cm}^{-1} ;{ }^{1} \mathrm{H}$ NMR $\left(600 \mathrm{MHz}, \mathrm{CDCl}_{3}\right)$ data, see Table $2 ;{ }^{13} \mathrm{C} \mathrm{NMR}(150 \mathrm{MHz}$, $\mathrm{CDCl}_{3}$ ) data, see Table 5; HRESIMS $\mathrm{m} / \mathrm{z} 273.1465$ $[\mathrm{M}+\mathrm{Na}]^{+}$(calcd for $\left.\mathrm{C}_{15} \mathrm{H}_{22} \mathrm{O}_{3} \mathrm{Na}, 273.1461\right)$.

\subsubsection{Irpexolactin I (10)}

Colorless oil; $[\alpha]_{\mathrm{D}}^{26}+2.7(c 0.10, \mathrm{MeOH}) . \mathrm{UV}(\mathrm{MeOH}) \lambda_{\max }$ $\mathrm{nm}(\log \varepsilon): 210$ (3.15); IR (KBr) $\nu_{\max } 3427,2926,2856$, 1714, 1633, 1386, $1031 \mathrm{~cm}^{-1}$; ${ }^{1} \mathrm{H}$ NMR (600 MHz, $\left.\mathrm{CDCl}_{3}\right)$ data, see Table $2 ;{ }^{13} \mathrm{C}$ NMR (150 MHz, $\mathrm{CDCl}_{3}$ ) data, see Table 5; HRESIMS $m / z 315.1560[\mathrm{M}+\mathrm{Na}]^{+}$(calcd for $\left.\mathrm{C}_{17} \mathrm{H}_{24} \mathrm{O}_{4} \mathrm{Na}, 315.1567\right)$.

\subsubsection{Irpexolactin J(11)}

Colorless oil; $[\alpha]_{\mathrm{D}}^{25}+17.1($ c $0.08, \mathrm{MeOH})$. UV (MeOH) $\lambda_{\max } \mathrm{nm}(\log \varepsilon): 219$ (3.74); IR (KBr) $\nu_{\max } 3426,2928,2869$, $1732,1633,1452,1389,1031 \mathrm{~cm}^{-1} ;{ }^{1} \mathrm{H}$ NMR $(600 \mathrm{MHz}$, $\left.\mathrm{CDCl}_{3}\right)$ data, see Table 2; ${ }^{13} \mathrm{C} \mathrm{NMR}\left(150 \mathrm{MHz}, \mathrm{CDCl}_{3}\right)$ data, see Table 5; HRESIMS $\mathrm{m} / z 273.1467[\mathrm{M}+\mathrm{Na}]^{+}$(calcd for $\mathrm{C}_{15} \mathrm{H}_{22} \mathrm{O}_{3} \mathrm{Na}, 273.1461$ ).

\subsubsection{Irpexolactin K (12)}

Colorless oil; $[\alpha]_{\mathrm{D}}^{26}+23.1($ c $0.08, \mathrm{MeOH})$. UV (MeOH) $\lambda_{\max } \mathrm{nm}(\log \varepsilon): 208$ (3.83); IR (KBr) $\nu_{\max } 3427,2927,2857$, $1633,1391,1028 \mathrm{~cm}^{-1}$; ${ }^{1} \mathrm{H}$ NMR $\left(600 \mathrm{MHz}, \mathrm{CDCl}_{3}\right)$ data, see Table $3 ;{ }^{13} \mathrm{C}$ NMR $\left(150 \mathrm{MHz}, \mathrm{CDCl}_{3}\right)$ data, see Table 5; HRESIMS $m / z$ 277.1781 $[\mathrm{M}+\mathrm{Na}]^{+}$(calcd for $\mathrm{C}_{15} \mathrm{H}_{26} \mathrm{O}_{3} \mathrm{Na}$, 277.1774).

\subsubsection{Irpexolactin L (13)}

Colorless oil; $[\alpha]_{\mathrm{D}}^{25}+78.3(c 0.10, \mathrm{MeOH})$. UV $(\mathrm{MeOH})$ $\lambda_{\max } \mathrm{nm}(\log \varepsilon): 210$ (3.73); IR (KBr) $\nu_{\max } 3438,2925,2856$, $1631,1385,1030 \mathrm{~cm}^{-1} ;{ }^{1} \mathrm{H}$ NMR $\left(600 \mathrm{MHz}, \mathrm{CDCl}_{3}\right)$ data, see Table $3 ;{ }^{13} \mathrm{C}$ NMR $\left(150 \mathrm{MHz}, \mathrm{CDCl}_{3}\right)$ data, see Table 5;

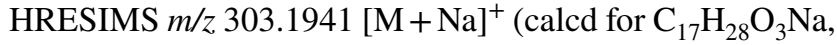
303.1941).

\subsubsection{Irpexolactin $M(14)$}

Colorless oil; $[\alpha]_{\mathrm{D}}^{26}+96.1(c 0.10, \mathrm{MeOH})$. UV $(\mathrm{MeOH})$ $\lambda_{\max } \mathrm{nm}(\log \varepsilon): 207$ (4.14), 252 (2.53); IR (KBr) $\nu_{\max } 3426$, 2927, 2866, 1633, 1385, $1028 \mathrm{~cm}^{-1}$; ${ }^{1} \mathrm{H}$ NMR $(600 \mathrm{MHz}$, $\left.\mathrm{CDCl}_{3}\right)$ data, see Table $3 ;{ }^{13} \mathrm{C} \mathrm{NMR}\left(150 \mathrm{MHz}, \mathrm{CDCl}_{3}\right)$ data, see Table 5; HRESIMS $m / z, 277.1778[\mathrm{M}+\mathrm{Na}]^{+}$(calcd for $\left.\mathrm{C}_{15} \mathrm{H}_{26} \mathrm{O}_{3} \mathrm{Na}, 277.1774\right)$.

\subsubsection{Irpexolactin N (15)}

Colorless oil; $[\alpha]_{\mathrm{D}}^{25}+21.2($ c 0.04, MeOH). UV (MeOH) $\lambda_{\max } \mathrm{nm}(\log \varepsilon): 208$ (3.76), 250 (3.06); IR (KBr) $\nu_{\max }$ 3422, 2928, 2859, 1721, 1630, 1457, 1384, 1266, 1093, $1031 \mathrm{~cm}^{-1}$; ${ }^{1} \mathrm{H}$ NMR $\left(600 \mathrm{MHz}, \mathrm{CDCl}_{3}\right.$ ) data, see Table 3; ${ }^{13} \mathrm{C}$ NMR (150 MHz, $\mathrm{CDCl}_{3}$ ) data, see Table 5; HRESIMS $m / z 319.1871[\mathrm{M}+\mathrm{Na}]^{+}$(calcd for $\mathrm{C}_{17} \mathrm{H}_{28} \mathrm{O}_{4} \mathrm{Na}, 319.1880$ ).

\subsubsection{Single-Crystal X-ray Diffraction Data of 1}

Colorless crystals of $\mathbf{1}$ were obtained by crystallization from $\mathrm{MeOH} / \mathrm{H}_{2} \mathrm{O}$ /petroleum ether. The crystal data were obtained from an APEX II DUO spectrophotometer (Bruker AXS GmbH, Karlsruhe, Germany) using graphite-monochromated $\mathrm{Cu} \mathrm{K} a$ radiation $(\lambda=1.54178 \AA$ ). The structures of $\mathbf{1}$ were solved by the direct method employing the SHELXS-97 program and then refined with full-matrix least-squares difference Fourier techniques. Crystallographic data of compound $\mathbf{1}$ was deposited to the Cambridge Crystallographic Data Centre (No. CCDC 1823228). These data can be obtained free of charge via https://www.ccdc.cam. ac.uk/conts/retrieving.html. Crystal data for $\mathrm{Cu} \_\mathbf{1} \_0 \mathrm{~m}$ : $\mathrm{C}_{16} \mathrm{H}_{26} \mathrm{O}_{4}, M=282.37, a=5.8192(2) \AA, b=9.6527(4)$ $\AA, c=13.5674(6) \AA, \alpha=90^{\circ}, \beta=93.526(2)^{\circ}, \gamma=90^{\circ}$, $V=760.65(5) \AA^{3}, T=100(2) \mathrm{K}$, space group $P 21, Z=2$, $\mu(\mathrm{CuK} \alpha)=0.702 \mathrm{~mm}^{-1}, 6956$ reflections measured, 2415 independent reflections $\left(R_{\text {int }}=0.0287\right)$. The final $R_{l}$ values were $0.0300(I>2 \sigma(I))$. The final $w R\left(F^{2}\right)$ values were 0.0797 $(I>2 \sigma(I))$. The final $R_{1}$ values were 0.0302 (all data). The final $w R\left(F^{2}\right)$ values were 0.0799 (all data). The goodness of fit on $F^{2}$ was 1.070. Flack parameter $=0.15(6)$.

\subsubsection{Single-Crystal X-ray Diffraction Data of 20}

A light colorless platelet-like of $\mathrm{C}_{15} \mathrm{H}_{26} \mathrm{O}_{3}, M=254.36$, approximate dimensions $0.095 \times 0.116 \times 0.263 \mathrm{~mm}^{3}$, was used for the X-ray crystallographic analysis on the BRUKER D8 QUEST diffractometer. The integration of the data using a monoclinic unit cell yielded a total of 12,363 reflections 
to a maximum $\theta$ angle of $79.29^{\circ}(0.78 \AA$ resolution), of which 3012 were independent (average redundancy 4.105, completeness $\left.=98.1 \%, \mathrm{R}_{\mathrm{int}}=5.36 \%, \mathrm{R}_{\mathrm{sig}}=5.40 \%\right)$ and 2848 $(94.56 \%)$ were greater than $2 \sigma\left(\mathrm{F}^{2}\right)$. The final cell constants of $\underline{a}=6.1670(3) \AA, \underline{b}=7.7139(4) \AA, \underline{c}=15.5645(8) \AA$, $\alpha=90.00^{\circ}, \beta=93.047(2)^{\circ}, \gamma=90.00^{\circ}, V=739.38(6) \AA^{3}$, $\mathrm{T}=150$.(2) K. Data were corrected for absorption effects using the Multi-Scan method (SADABS). The structure was solved and refined using the Bruker SHELXTL Software Package, using the space group P 121 , with $Z=2$, $\mu(\mathrm{CuK} \alpha)=1.54178$. The final anisotropic full-matrix leastsquares refinement on $\mathrm{F}^{2}$ with 174 variables converged at $\mathrm{R} 1=3.54 \%$, for the observed data and $\omega R^{2}=8.84 \%$ for all data. The goodness-of-fit was 1.009. The absolute configuration was determined by the Flack parameter $=0.01(9)$, which was determined using 1165 quotients $[(\mathrm{I}+)-(\mathrm{I}-)] /$ $[(\mathrm{I}+)+(\mathrm{I}-)]$. Crystallographic data of compound $\mathbf{2 0}$ was deposited to the Cambridge Crystallographic Data Centre (No. CCDC 1977047). These data can be obtained free of charge via https://www.ccdc.cam.ac.uk/conts/retrieving.html.

\subsection{Vasorelaxant Effect Assay}

\subsubsection{Animals}

Adult male Wistar rats (250-300 g) were kept in an animal room with a constant temperature of $22 \pm 2{ }^{\circ} \mathrm{C}$, a humidity of $60 \pm 5 \%$ and had free access to food and water. Experiments were performed in accordance with the guidelines of the National Institutes of Health Guide for the Care and Use of Laboratory Animals. All experimental procedures were approved by the Research Ethics Committee of the Kunming Institute of Botany, Chinese Academy of Sciences.

\subsubsection{Methods}

Vasorelaxant effects of $100 \mu \mathrm{mol} / \mathrm{L}$ of the compounds was evaluated on endothelium-intact thoracic aorta rings precontracted with $\mathrm{KCl}$. Rat aortic rings were prepared according to that described $[16,17]$. Nifedipine, a calcium channel blocker, was used as the positive control. Aortic rings were mounted on stainless steel hooks in organ baths containing $37{ }^{\circ} \mathrm{C}$ Krebs solution continuously bubbled with $95 \% \mathrm{O}_{2}$ and $5 \% \mathrm{CO}_{2}$, then equilibrated for $60 \mathrm{~min}$ under a resting tension of $1.5 \mathrm{~g}$. After equilibration, the vessels were exposed to $1 \mu \mathrm{mol} / \mathrm{l}$ phenylephrine (PE), followed by $10 \mu \mathrm{mol} / 1$ acetylcholine (Ach) to check functional endothelial integrity, more than $80 \%$ relaxation of the rings was considered to be an endothelium-intact ring. Endothelium-intact rings precontracted with $60 \mathrm{mmol} / \mathrm{l} \mathrm{KCl}$ were treated with different compounds, DMSO or nifedipine for $30 \mathrm{~min}$ or $60 \mathrm{~min}$, the changes in tension of aortic rings were recorded. The vasorelaxant effect was calculated as a percentage of the relaxation in response to $\mathrm{KCl}$ on the aortic rings. Data were presented as mean \pm SD and evaluated by one-way ANOVA followed by Bonferroni's test using SPSS 19.0. $\mathrm{P}<0.05$ was regarded to be statistically significant.

Acknowledgements This work was financially supported by National Natural Science Foundation of China (Nos.81903512, 21961142008). We thank Analytical \& Measuring Center, School of Pharmaceutical Sciences, South-Central University for Nationalities for MS and NMR spectra tests.

\section{Compliance with Ethical Standards}

Conflict of interest The authors declare no conflict of interest.

Open Access This article is licensed under a Creative Commons Attribution 4.0 International License, which permits use, sharing, adaptation, distribution and reproduction in any medium or format, as long as you give appropriate credit to the original author(s) and the source, provide a link to the Creative Commons licence, and indicate if changes were made. The images or other third party material in this article are included in the article's Creative Commons licence, unless indicated otherwise in a credit line to the material. If material is not included in the article's Creative Commons licence and your intended use is not permitted by statutory regulation or exceeds the permitted use, you will need to obtain permission directly from the copyright holder. To view a copy of this licence, visit http://creativecommons.org/licenses/by/4.0/.

\section{References}

1. H.P. Chen, J.K. Liu, Prog. Chem. Org. Nat. Prod. 106, 1-201 (2017)

2. X.M. Dong, X.H. Song, K.B. Liu, C.H. Dong, Mycosystema 36, 28-34 (2017)

3. W.A. Ayer, E.R. Cruz, J. Org. Chem. 58, 7529-7534 (1993)

4. J.H. Ding, T. Feng, B.K. Cui, K. Wei, Z.H. Li, J.K. Liu, Tetrahedron Lett. 54, 2651-2654 (2013)

5. J.H. Ding, Z.H. Li, T. Feng, J.K. Liu, Fitoterapia 125, 245-248 (2018)

6. J.H. Ding, Z.H. Li, T. Feng, J.K. Liu, Nat. Prod. Res. 33, 316-320 (2019)

7. L.L. Chen, F.D. Kong, P. Wang, J.Z. Yuan, Z.K. Guo, H. Wang, H.F. Dai, W.L. Mei, Chin. Chem. Lett. 28, 222-225 (2017)

8. H.P. Chen, M.Y. Jiang, Z.Z. Zhao, T. Feng, Z.H. Li, J.K. Liu, Nat. Prod. Bioprospect. 8, 37-45 (2018)

9. X.Y. Yang, T. Feng, X. Yin, Z.H. Li, L. Zhang, J.K. Liu, Chin. J. Chem. 30, 1231-1235 (2012)

10. Z.Y. Zhou, J.G. Tang, F. Wang, Z.J. Dong, J.K. Liu, J. Nat. Prod. 71, 1423-1426 (2008)

11. D.Z. Liu, F. Wang, J.K. Liu, J. Nat. Prod. 70, 1503-1506 (2007)

12. Y.M. Ying, W.G. Shan, L.W. Zhang, Z.J. Zhan, Phytochemistry 95, 360-367 (2013)

13. L.Y. Liu, Z.H. Li, J. Si, Z.J. Dong, J.K. Liu, J. Asian Nat. Prod. Res. 15, 300-304 (2013)

14. X.L. Wu, S. Lin, C.G. Zhu, Z.G. Yue, Y. Yu, F. Zhao, B. Liu, J.G. Dai, J.G. Shi, J. Nat. Prod. 73, 1294-1300 (2010)

15. R.H. Yin, Z.Z. Zhao, H.P. Chen, X. Yin, X. Ji, Z.J. Dong, Z.H. Li, T. Feng, J.K. Liu, Phytochem. Lett. 10, 300-303 (2014)

16. G.J. Chang, T.P. Lin, Y.S. Ko, M.S. Lin, Life Sci. 86, 869-879 (2010)

17. X. Ji, C.C. Trandafir, A.M. Wang, K. Kurahashi, J. Stroke Cerebrovasc. 22, 1258-1262 (2013) 